Trakya Eğitim Dergisi

Cilt 11, Say1 3

Eylül 2021, 1637-1659

Geliş Tarihi: 07.06.2021

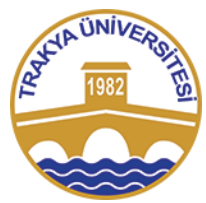

ISSN: $2630-6301$

Doi: $10.24315 /$ tred.949068

Araştrrma Makalesi
Trakya Journal of Education

Volume 11, Issue 3

September 2021, 1637-1659

Yayına Kabul Tarihi:14.07.2021

Research Article

\title{
GAGAUZ TÜRKÇESİNDE İKİLEMELER
}

\section{REPUBLICATIONS IN GAGAUZ TURKISH}

\section{Levent DOĞAN ${ }^{1}$}

Öz: İkilemeler, sadece yan yana gelmiş iki sözcüğün tekrarından ibaret olmayan, bu yolla yeni kavramlar inşa ederek anlamı ve anlatımı güçlendiren dil birlikleridir. Türkçenin en eski dönem eserlerinde dahi kullanımına atıfta bulunulan ikilemeler, anlamı pekiştirmesinin yanı sıra ifadeye renk ve estetik katarlar. Bu açıdan özellikle âşık, şair ve yazarların bir yapıt vücuda getirirken sıklıkla başvurduğu ifade kalıpları olmuşlardır. İkilemelerde söz konusu etkileri sağlayan anlamsal, yapısal ve ses bilimsel özellikler vardır. Bu yüzden ikilemeler taşıdıkları nitelikler bakımından ele alınması gereken bir konudur. Türk dil biliminde konuyla ilgili kapsamlı araştırmalar yapılmıştır. Benzer araştırma ve incelemelerin Türkçenin çoğu lehçesinde de uygulandığı müşahede edilmiştir. $\mathrm{Bu}$ çalışmada, Gagauz Türkçesiyle ilgili sözlüklerden, şiir kitaplarından ve diğer birçok kaynaktan tespit edilen ikilemeler; anlam, köken, yap1, sözcük türü ve diziliş olarak çeşitli yönlerden incelenmiştir. İnceleme sonucunda elde edilen veriler sonuç kısmında detaylandırılmıştır.

Anahtar Sözcükler: Gagauz Türkçesi, ikileme, yapı, diziliş, anlam

\begin{abstract}
Reduplications are not only repetition of th words coming side by side but also they are collocation reinforcing meaning and expression by building ne concepts. The reduplications to which there is reference Turkish works of the oldest period, adds color and aestheti to expression as well as reinforcing the meaning. From th respect they have been expression patterns to whis especially minstrels, poets and authors resort frequent while creating a work. There are lexical, stuctur phonological features providing the given effects in th reduplications. Therefore reduplication is a subject th needs to be handled in terms of qualifications that they hol Comprehensive researches have been carried out related the subject in Turkish Lingustics. It has been observed th similar researches and studies have been carried out in mo dialects of Turkish. In this study, reduplications determin from dictonaries, poetry books, and many other resourc related to Gagauz Turkish have been researched in terms , semantics, lexis structure, etymon, formation, word type ar sequence. The data acquired as a result of this study $h$ : been detailed in the conclusion part.
\end{abstract}

Keywords: Gagauz Turkish, redublication, structur sequence, semantics

\section{Bu makaleye atıf vermek için:}

Doğan, L. (2021). Gagauz Türkçesinde ikilemeler, Trakya Eğitim Dergisi, 11(3), 1637-1659

Cite this article as:

Doğan, L. (2021). Redublications in Gagauz Turkish. Trakya Journal of Education, 11(3), 1637-1659

\section{EXTENDED ABSTRACT}

\section{Introduction}

Reduplications have important place in Turkish Vocabulary. The reduplications whose samples are witnessed in the oldest scripts of Turkish, are expression patterns used widely in every period of our language. The main purposes of reduplications are reinforcing the meaning, adding richness and strength to the expression. There are various definitions for this expression patter.

However, mostly term ikileme (reduplication) is preferred. The word ikileme covered with other terms in Turkish dialects is used as ikilemäk in Gagauz Turkish.

\footnotetext{
${ }^{1}$ Dr. Öğr. Üyesi, Trakya Üniversitesi, Edirne/Türkiye, ldogan@ trakya.edu.tr, ORCID: 0000-0002-0538-4002
} 
The reduplications have obtrusive features with respect to sound and form. There is harmony among the sounds creating the reduplication. This harmony or tune felt in the articulation is the leading factor increasing their strength of expression and effect.

There are specific elements reinforcing patterning in the reduplication. These elements: the precedence of the one with less syllables between the components, precedence of the component starting with vowel, precedence of Turkish component to the foreign component, and that the components starting with the letters "b" or "p" be secondary component. (Hatiboğlu 1981: 16-18). First two elements are in "the section of the reduplications with respect to sequence". If we test other two on reduplications in Gagauz Turkish: Turkish word precedes the foreign word in reduplications of this field: al-pemba (CTL 162), emiş-meyva (GTASGSV), soruş-cuvap (GRRS). The same as Turkish reduplications, the components starting with the letters "b" or "p" be secondary component: aykırt-buykuru (GRRS), çatra-patra (GRRS), harç-borç (GASÜBD. 1183), harça-parça (GRRS), türlü-bürlü (GRRS), senek-benek (GY. 166), şaş-beş $(G R R S)$ etc. A few examples of duplications where the components starting with the letters "b" or "p" is preceding component have been encountered: pak-duruk (SS. 100) bü̈̈-küçüü (SS. 147), büün yarın (GTYYÜ. 94).There are researches related to reduplications in most of Turkish dialects. However a separate study on reduplications in Gagauz Turkish has not been encountered. In this study the varieties and features of reduplications in Gagauz Turkish have been explained.

\section{Method}

In this study the publications related to Gagauz Turkish have been searched in order to determine the reduplications. The primary source of our study is "Gagauzian -Russian -Romanian Dictionary". First of all the reduplications within this dictionary have been determined. Then articles, books and academic dissertations written about various subjects in Gagauz Turkish have been searched. Numerous reduplications collected at the end of this process have been handled in terms of semantics, lexis structure, etymon, formation, word type and sequence.

\section{Findings, Discussion and Conclusion}

225 reduplications from the dictionary which constites the main source of study and 424 reduplications from other resources have been collected. The reduplications formed by reinforcing and the states of reduplications which have various affixes are included in these numbers. The figures given are regarded as concrete proof of the strenght of Gagauz Turkish in expression and variety and richness it has in reduplication.

The reduplications in Gagauz Turkish have been subdivided in 6 groups. Among these groups the ones which are formed by repeating the same word constitutes the majority in terms of quantity. This is followed by the ones formed by repeating words with close meaning or synonym words. In the third rank there are reduplications formed with reflection words. In the reflection duplications there are a few examples whose two components are different such as läk-tık, dum-çık, hop-zup. Moreover reflections in the form of triplication have been encountered during the search : çın-çın-çın (SS. 231), vrak-vrak-vrak (GÇŞA. 46) etc. Ranking among the rest three titles is that the ones formed with two words with antonym meaning, the ones formed with two words one of which is meaningful the other one is meaningless, and the repetition of two meaningless words.

It has been observed that various suffixes play role in the formation of the reduplications studied in terms of structure after the semantics. In the reduplications formed with case suffixes, these suffixes are sometimes affixed to both components sometimes only to one component. For example: In the reduplication doorudan dooruya both components have taken case suffix. This type of reduplication is frequently encountered in Gagauz Turkish. In the given example both components have taken different case suffixes.

The examples in which both component take same case suffix are more frequent. anaylan-bobaylan (GRRS), arpadan boodaylardan (GÇŞA. 50), erdä-göktä (GTTIFÇK. 89), kırın-daayın (SS. 67), saayasola $($ SS. 81) vb. 
Secondly observed situation is that the case suffixes are affixed only to the second component "aaz-aaza (GRRS), kar-kışında (GHT. 137), kış-yazın (GÇŞA. 156)" or only to the first component "aariflerdänaarif (SS. 31), bobaylan ool (GY. 143)"

Substitution among the case suffixes in Gagauz Turkish are observed in the reduplications too. In the highlighted parts of the reduplications below accusative case suffix to the first one and ablative case suffix to the second one instead of dative suffix case are used. orayl-buray "oraya buraya" (KK. 154), kol-koldan "kol kola" etc.

Dative suffix case and ablative suffix case are the ones constituting the majority of the reduplications formed with case suffixes.

The reduplications formed with various derivational affixes are two types as derived from noun and verb. In the reduplications derived from the noun derivational suffixes such as $+l l,+l \imath k /+n \imath k,+s l z,+c l k /+c u ̈ k$ are used while - ak derivational suffix is assigned in reduplications derived from verbs. An example in which both component takes different derivational suffix has been determined: belli-belersiz (KK. 202). Furthermore an example in which derivational suffix is affixed to the first component has been determined: saallk-kısmet (SS. 159).

In Gagauz Turkish the ones formed with verbal adverbs are majority among the reduplications formed with verbals. The number of reduplications taking $-a /-e /-\ddot{a}$ suffix are more. There are examples formed with verbal adverbs apart from this suffix.

In Gagauz Turkish the reduplications made up from inflected verbs the first and second component generally inflected with the same tense: annat annat (GTG. 196), giindi kuşandı (GTTIFÇK. 217) etc. Two samples in which both components inflected with different tenses have been observed: gidärsängeleceklär (GTG. 215), sayarsan-sayacaklar (GTG. 215). Yet the reduplications formed with repeatition of positive and negative inflection of the same verb stands out.: ağla ağlama (GÇŞA. 272), bastımbasmadim (ÇTLEK. 159), inan-inanma (GÇŞA. 272).It is observed that reduplications formed with the first component taking verbal adverb suffix and the second one taking the inflectional suffix are used to add abundance and contrast to the meaning: eşerdikçä eşerer (GTG. 173), gidip-gelärsin (GÇŞA. 154), suuyup-terleer (SS. 64).

In Gagauz Turkish reduplications are formed with nouns, pronouns, adjective, adverb, exclamation, conjuction and verbs. In this field, the reduplications formed with adjectives and adverbs are more frequently used that the ones formed with pronouns.

The reduplications formed with numbers are sorted with ascendingly as in Turkey Turkish.

In Gagauz Turkish some reduplications are two in two ways. One reduplication has been encountered both as karpuz-kaun (GÇŞA. 60) and kaun karpuz (GTASGSV) in different resources.

Lastly, the reduplications in Gagauz Turkish have been handled with sequencing principals determined with reduplications in Turkey Turkish. As a result of this it has been observed that the reduplications in Gagauz Turkish are sequenced in a similar way as in reduplications in Turkey Turkish. For instance, the words with less syllables precede in reduplications of Gagauz Turkish, the example of the opposite situation has been encountered less. It has been determined that the reduplications within this group are generally in the sequence of $1+2$ syllable. In addition, it has been determined that the rules such as the fact that the element starting with the vowel comes first in reduplications with equal syllables, that both elements continue with the same consonant after the vowels in the leading or inner voice, and the invariant consonant sequences determined by Tuna are also valid in Gagauz Turkish reduplications. Examples of invariable vowel sequencing, that fit most, if not all, have been encountered.

\section{GİRIŞ}

İkilemeler, Türkçenin en eski devirlerinden beri dilimizde yaygın olarak kullanılan kalıplaşmış söz öbekleridir. Gerek sözlü gerek yazılı anlatımda kullanımına sıklıkla başvurulan ikilemelerin temel işlevi anlamı pekiştirmek, ifadeye güç ve zenginlik katmaktır. Hint-Avrupa dillerinde çok az örneğine rastlanılan ve Türkçedeki kadar yaygın kullanıma sahip olmayan ikilemeler, Türkçenin anlatım gücünü ve zenginliğini gösteren unsurlardır (Aksan, 2006: 81).

İkileme, dünya dillerinden Almancada gemination, verdoppelung, reduplikation, Fransızcada gemination, zwillingsformen, reduplication, redoublement, İngilizcede gemination, hendiadyoin, reduplication, dual terimleriyle karş1lanır (Vardar, 2002: 119; Hatiboğlu, 1981: 9). Türkçede bu ifade 
kalıbı için genellikle ikileme teriminin tercih edildiği görülür. Fakat ikileme yerine çalışmalarında; tekrarlar (Ergin, 2013; Açıkgöz ve Yelten, 2005; Tuna 1949), bağlam öbeği (Banguoğlu, 2015), kelime koşmaları (Ağakay, 1954), ikilemeler ve ikizlemeler (Gencan, 1979), hendiadyoin (Çağatay, 1978; Aydın, 1997), tekrar grubu (Karahan, 2013), ikiz kelime, katmerleme, yakın anlamlı çift (bkz. Yücel, 2016: 81) gibi farklı tabirler kullanan araştırmacılar da vardır. Türk lehçelerinde de başka terimlerle karşılanan ikileme sözcüğü Gagauz Türkçesinde ikilemäk şeklinde kullanılır.

Türk dilinde ikileme konusu pek çok araştırmacı tarafından çeşitli şekillerde ele alınıp irdelenmiştir. Bu hususta öncelikli olarak anılması gereken araştırmacılar Mehmet Ali Ağakay, Vecihe Hatiboğlu, Osman Nedim Tuna, Muharrem Ergin ve Zeynep Korkmaz'dır.

İkileme terimi kaynaklarda benzer şekillerde tanımlanmıştır. Bazı araştırmacılar çalışmalarında tanımla beraber ikilemelerin sınıflandırılması konusuna da eğilmiştir. Bunlardan birkaçına yer verecek olursak; Vecihe Hatiboğlu (1981: 9), “Türk Dilinde İkilemeler” kitabında ikileme için "Anlatım gücünü artırmak, anlamı pekiştirmek, kavramı zenginleştirmek amacıyla, aynı sözcügün tekrar edilmesi veya anlamları birbirine yakın yahut karşıt olan ya da sesleri birbirini andıran iki sözcügü̈n yan yana kullanılmasıdır." tanımını yapmıştır. Hatiboğlu (1981: 5-6-7), ikilemeleri tüm incelikleriyle ele aldığı bu eserinde oldukça kapsamlı bir sınıflandırma yapmıştır. Hatiboğlu'nun sınıflandırmasındaki 7 ana başlık şu şekildedir: Sözcük Yapısı Bakımından İkileme Türleri, Aralıklı İkilemeler, Sözcük Türü Bakımından İkilemeler, Yapı ve Kuruluş Bakımından İkilemeler, Görev Bakımından İkilemeler, Anlam Bakımından Ikkilemeler ve Anlam Bakımından İkilemeyi Kuran Sözcükler. Bu ana başlıklar içerisinde de pek çok alt başlık oluşturan Hatiboğlu, Türkçedeki ikilemeleri detaylı bir şekilde sınıflayarak incelemiştir.

Muharrem Ergin (2013: 377-379), “Türk Dil Bilgisi” kitabında "tekrarlar” başlığı altında ikilemeyi "Tekrarlar aynı cinsten iki kelimenin arka arkaya getirilmesi ile meydana gelen kelime gruplarıdır." şeklinde tanımlamıştır. Ergin, aynı kitabında ikilemeleri aynen tekrarlar, eş manalı tekrarlar, zıt manalı tekrarlar, ilaveli tekrarlar biçiminde sınıflandırmıştır.

Tahir Nejat Gencan (1979: 191-193), "Dilbilgisi" eserinde ikilemeleri, ikilemeler ve ikizlemeler olarak iki ayrı başlıkta ele almıştır. Gencan, ikilemeler başlığında sadece aynı sözcüğün tekrarıyla yapılan ikilemelere, ikizlemeler başlığında ise yakın, eş ve zıt anlamlı sözcüklerin tekrarıyla yapılan ikilemelere yer vermiştir. İkileme ve ikizlemelerin anlatıma duygusal nüanslar, çeşitlilik ve genişlik katmak için oluşturulduğunu belirtmiştir. Çalışmasında ikilemelerle ilgili herhangi bir sınıflama sunmayan Gencan, kalıplaşmış biçimdeki bu öbeklerin sözcük türü ve yapı bakımından çeşitli oluğunu ifade etmiştir.

Zeynep Korkmaz (2010: 123), “Gramer Terimleri Sözlüğü”nde ikilemeleri “Aralarında belli bir ses düzeni bulunan, biçim ve anlamca birbiriyle ilişkili olan, aynı, yakın ya da zıt anlamlı iki veya daha çok kelimenin bir tek kelime gibi anlam göstermek üzere yan yana gelmesiyle oluşturulan kelime grubu." olarak tarif etmiştir.

Nevzat Özkan (1996: 195-198), “Gagavuz Türkçesi Grameri” adlı eserinde ikileme için "Fonksiyonları, şekilleri ve genellikle vurguları birbirinden farksız olan aynı cinsten iki kelimenin arka arkaya getirilmesi ile meydana gelen kelime gruplarıdır." (1996: 195) tanımını yapmıştır. Özkan, "Gagavuz Türkçesi Grameri” adlı kitabında ikilemeleri, kelime grupları bölümünde tekrarlar (ikilemeler) başlığı altında ele almış ve aynen tekrarlar, eş anlamlı tekrarlar, zıt anlamlı tekrarlar, eklemeli tekrarlar ve ses yakınlı̆̆ına dayalı tekrarlar şeklinde 5 grupta incelemiştir.

Mehmet Ali Ağakay ve Osman Nedim Tuna ikilemelerin ses düzeniyle ilgili çalışmalar yapmıştır. İkilemelerde diziliş sırasının önemine vurgu yapan Ağakay (1954: 100-103), bu sıranın değiştirilmesi hâlinde bazı ikilemelerin ya anlaşılmaz olacağından ya da bambaşka bir anlam vereceğinden söz etmiştir. $\mathrm{Bu}$ açıdan ikilemelerin diziliş sırasını anlam ve ses olmak üzere iki esasa dayandırmıştır. Ağakay, çalı̧̧masında ikilemeleri önce mantıkî sıraya göre dizmiştir. Mantıkî açıdan bir sıra göstermeyen ikilemelerin dizi sırasını ise ses özelliklerine göre düzenlemiştir.

Osman Nedim Tuna (1983: 163-228), eş heceli ikilemelerde sıralamayı sağlayan seslerin neler olduğunu tespit ederek bunların değişmez bir sıra takip edip etmediği üzerinde durmuştur. Tuna, eşit heceye sahip ikilemelerdeki diziliş sırasını Mehmet Ali Ağakay'ın yazısından yola çıkarak geliştirdiğini belirtmiştir.

Buraya kadar bahsedilenlerden de anlaşıldığı üzere ikilemeler, ses ve biçim bakımından dikkati çeken özelliklere sahiptir. İkilemeyi oluşturan seslerin birbiri arasındaki uyum bu söz öbeğinin önemli bir özelliğidir. Bir ikilemedeki seslerin söyleyişte hissedilen ahengi, onların ifade ve etki gücünü arttıran 
etkenlerin başında gelir. İkilemelerde ses ve biçime dayalı oluşan çeşitli tekrarlar da bu etkenler arasında yer alır. Söz konusu tekrarlar bazen doğru düzgün ikilemesindeki gibi ön ses, bazen sarmaş dolaş, giren çıkan örneklerinde olduğu gibi son ses ve biçim, bazen de kapı kapı gibi sözcük tekrarlarından meydana gelir. Bunların çeşitlerini arttırmak mümkündür. Ayrıca yansıma yoluyla oluşan tekrarların bir kavramı adeta canlandırarak anlatması ikilemelerin anlatım gücüne başka bir örnektir (Aksan 2016: 222-223).

İkilemeler, ses ve biçim açısından olduğu kadar semantik açıdan da ilgi çeken bir nitelik taşır. Doğan Aksan (2016: 128), ikilemeleri bu açıdan birleşik sözcüklere benzetir. İkilemelerde de birleşik sözcüklerdeki gibi iki farklı göstergeye karşılık tek bir gösterilen vardır. Bu göstergeler birleşerek tek bir gösterge hâlini alır ve belirli bir kavramı karşılar duruma gelir. Aslında bunda, ikilemeyi oluşturan her iki sözcüğün tek başınayken sahip olduğu gösteren ve gösterilenin rolü vardır. Bu iki göstergenin zihindeki tasarımları yeni bir gösterge ya da kavramın doğmasına yardımcı olur. Bunu "kör topal" ikilemesini ele alarak açıklayan Aksan, "kör" ve "topal" sözcüklerinin ifade ettiği anlamlar ile zihinde yer alan tasarımlarının "kusurlu, zoraki götürülen iş" anlamında yepyeni bir kavram oluşturduğunu belirtir. İkilemelerin her çeşidi farklı bir anlam boyutuna sahiptir. Ses tekrarlarının göze çarptığı ikilemeler (dügün dernek, baldır bacak, az buz, bölük pörçük, eski püskü) ile aynı sözcügün tekrarına dayalı ikilemelerde (sabah sabah, demet demet) daha çok kavramın pekiştirilmesi söz konusudur. Fakat bütün ikileme çeşitleri canlı ve zengin bir anlatım sağlaması, anlamı pekiştirmesi yönüyle ortak bir işleve sahiptir (Aksan 2016: 129).

Vecihe Hatiboğlu (1981: 55-57), ikilemenin en önemli amacının anlamı pekiştirmek olduğunu belirtir. Bununla beraber ikilemenin anlamı güçlendirme, abartma ve çoğaltma amaçlarından bahseder. Ayrıca ikilemenin diğer anlatım çeşitlerine göre bir durumu daha kolay açıkladığından söz eder. Yani ikilemelerin anlamayı ve anlatımı kolaylaştıran bir işlev taşıdığını açıklar.

Bilindiği gibi ikilemeler kalıplaşmış dil birlikleridir. Bu kalıplaşma o kadar ileri derecededir ki, ikilemelerde bazı unsurların yerleri değiştirilemez ya da bazıları da tek başlarına kullanılamazlar. Örneğin; e ğri bügrrü, tek tük, yırtık pırtık ikilemelerinde ikinci unsurlar tek başınayken bir anlamı bulunmayan ve ayrı kullanılmaya elverişli olmayan sözcüklerdir. Bu tip ikilemeler arasında beraber kullanılmayı gerekli kılan bir bağ vardır (Hatiboğlu, 1981: 15). Yine ikilemelerde önce kullanılan unsurun sonra, sonra kullanılan unsurun da önce kullanılması kalıplaşmayı bozan bir durumdur. Karı koca yerine koca karl ya da kör kötük yerine kütük kör şeklinde unsurların sırasını değiştirerek kullanmak anlamı değiştirip bozduğu gibi kalıplaşmayı ve ikilemeyi de ortadan kaldırır. Vecihe Hatiboğlu (1981: 15-16), kalıplaşma sayesinde ikilemelerdeki sözcüklerin dizilişs sırasının kendiliğinden belirlendiğini belirtir.

İkilemelerde kalıplaşmayı güçlendiren belirli etmenler vardır. Bunların bir kısmının ikilemelerin diziliş kuralları arasında yer aldığı görülür. Bu etmenler; iki unsur arasında az heceye sahip olanın önce gelmesi, ünlü ile başlayan unsurun başta yer alması, Türkçe unsurun yabancı unsurdan önce kullanılması ve "b" ya da "p" harfi ile başlayan unsurların ikinci unsur olması yani sonra gelmesidir (Hatiboğlu, 1981: 16-18). İlk iki etmen, çalışmamızın "diziliş bakımından ikilemeler kısmında" yer almıştır. Diğer ikisini Gagauz Türkçesindeki ikilemeler üzerinde denediğimizde; Bu saha ikilemelerinde de genellikle Türkçe sözcük yabanc1 sözcükten önce gelmiştir: al-pembä (ÇTLEK. 162), emiş-meyva (GTASGSV), kara-biyaz (SS. 8), saalık-kismet (SS. 159), soruş-cuvap (GRRS) vb. Tıpkı Türkiye Türkçesindeki ikilemeler gibi Gagauz Türkçesi ikilemelerinde de "b" ya da "p" ile başlayan unsurun ilk unsurdan sonra geldiği görülmüştür: ayktrı-buykuru (GRRS), cenk-benk (GTG. 198), çatlak-patlak (KK. 224, G. 119), çatrapatra (GRRS), harç-borç (GASÜBD. 1183), harça-parça "bkz. parça-parça" (GRRS), iiri-büürü (GRRS) kır-bayır (GRRS), türlü-bürlü (GRRS), senek-benek (GY. 166), şaş-beş (GRRS) vb. Başında "b" ya da "p" bulunan ikilemelerin ilk unsur olarak yer aldığı birkaç örnekle karşılaşılmıştır: pak-duruk (SS. 100) büüküçüü (SS. 147), büün yarın (GTYYÜ. 94).

Türkçede ikilemeler üzerine yapılan çalışma sayısı oldukça fazladır. Türkçenin çoğu lehçe ve ağızlarında ikilemelerle ilgili çalışmalar mevcuttur. Lehçeler özelinde konuyla ilgili literatür tarandığında; Türkmen Türkçesi (Doğan, 2012; Bozkurt, 2013), Kazak Türkçesi (Atmaca \& Kral, 2015), Kırgız Türkçesi (Ulutaş, 2007), Eski Uygur Türkçesi (Çağatay, 1978; Şen, 2002; Can, 2010; Ölmez, 2017), Yeni Uygur Türkçesi (Öztürk, 2008), Özbek Türkçesi (Öz, 1996), Yakut (Saha) Türkçesi (Kardeş, 2015), Altay Türkçesi (Dilek, 2004), Hakas Türkçesi (Kara, 2009), Azerbaycan Türkçesi (Yalçın \& Çeçen, 2020), Tatar ve Başkurt Türkçesi (Özşahin, 2017), Nogay Türkçesi (Atay, 2010) ve Kaşkay Türkçesi (Çelik \& Yılmaz, 2020)'nde ikilemelerin tespit edilerek ortaya koyulduğu görülür. 


\section{YÖNTEM}

\section{Araştırmanın Modeli}

İkilemeler, Türk dilinde gösterdiği çeşitlilik açısından önemli bir yere sahiptir. Dolayısıyla her lehçe için olduğu gibi Gagauz Türkçesindeki ikileme varlığının da ortaya çıkarılması gerekir. Derlemeye dayalı bu araştırmada, Gagauz Türkçesinde kullanılan ikilemeler ile bunların özellikleri ortaya koyulmaya çalışılmıştır. Bu doğrultuda Gagauz Türkçesiyle ilgili taranan pek çok kaynaktan derlenen ikilemeler, konuyla ilgili literatürde yer alan çalışmalar dikkate alınarak incelenmiştir.

\section{Çalışmanın Kapsamı ve Sınırlılıklar}

Yaşayan Türk lehçelerinden Gagauz Türkçesinde ikilemelerin ele alındığı bu çalışmada, olabildiğince çok ve farklı ikileme örneğine ulaşılmaya çalışılmıştır. Bu sebeple herhangi bir sınırlamaya gidilmemiş, içerisinde ikileme bulunan her tür kaynak kapsama dâhil edilmiştir. Toplamda 22 kaynak taranmıştır. Öncelikle Petri Çebotar ve Ion Dron'un hazırladığı “Gagauzça-Rusça-Romınca Sözlük”teki ikilemeler tespit edilmiştir. Daha sonra Gagauz Türkçesinde çeşitli konular üzerine yayımlanmış makale, kitap ve tezler taranmıştır. Bu kaynaklarda yer alan şiir, türkü, masal, mani, atasözü, deyim gibi türler içerisinde geçen ikilemeler saptanmıştır. Bunların yanı sıra Bülent Hünerli'nin yayıma hazırladığı "Mihail Çakir'in Gagauzca (Türkçe)-Rumence Sözlügü̈’ de taranmıştır.

\section{Verilerin Analizi}

İlk olarak belirtilen kaynaklardaki ikilemeler tarama yoluyla derlenmiştir. Derleme çalışmalarından sonra elde edilen ikilemeler makalenin başında belirtilen sınıflandırmalar ışı̆̆ında anlam, yapı ve diziliş̧ bakımından sınıflandırılarak analiz edilmiştir. Çalışmada yer alan ikilemelerin anlamları tırnak içerisinde, alındığı kaynak ise kısaltması ve sayfa numarası ile parantez içerisinde belirtilmiştir. Türkiye Türkçesi ile şekil ve anlam bakımından farklılık göstermeyen ikilemelerin açıklaması verilmemiştir. Bazı kaynaklardaki ikilemelerin arasına tire işareti (-) koyulmuş, bazılarında ise bu işaret kullanılmamıştır. Özetle çalışmada, taranan kaynaklarda geçen ikilemelerin şekil ve anlamlarına bağlı kalınmıştır. Değerlendirme sonucunda ulaşılan veriler çalışmanın sonuç kısmında detaylı bir şekilde ortaya koyulmuştur.

\section{BULGULAR}

\section{Gagauz Türkçesinde İkilemelerin Sınıflandırılması}

\section{Anlam Bakımından İkilemeler}

İkilemeler; anlam, ses, yap1 gibi farklı açılardan incelenebilir. Hatiboğlu (1981: 55), ikilemelerin oluşumunda anlamın etkisine vurgu yapmakta ve bunu "Türk düşüncesindeki durmadan gelişen anlamlara yeni kalıplar bulmak, kavramları belirtmek için, sözcükleri yan yana getirip tek bir sözcük gibi kullanma yoluna gidilmiştir. Böylece, anlamı belirtmek, pekiştirmek, güçlendirmek amacıyla yeni bir sözcük yaratır gibi, iki sözcük yan yana getirilir ve bu birlikten ortaklaşa yeni bir anlam, güçlü bir kavram elde edilir." ifadeleriyle açıklamaktadır.

İkilemeler, anlamlı iki sözcükten meydana gelebileceği gibi biri anlamlı diğeri anlamsız veyahut ikisi de anlamsız sözcüklerden de meydana gelebilir. Her iki sözcügü anlamlı olan ikilemeler; aynı sözcüğün tekrarıyla kurulanlar, eş ya da yakın ve zıt anlamlı iki sözcügün tekrarıyla kurulanlar olmak üzere genellikle üç şekilde gruplanır. Yansıma sözcüklerin tekrarıyla kurulan ikilemeler de anlam başlığı içerisinde değerlendirilebilir. Bu bölümde, Gagauz Türkçesindeki ikilemeler söz konusu başlıklar altında incelenmiştir.

\section{Aynı Anlamdaki Aynı İki Sözcüğün Yinelenmesiyle Kurulan İkilemeler}

Bu gruptaki ikilemeler aynı iki sözcüğün tekrarına dayanır. Asıl tekrarlar da denilen bu tür ikilemeler isim, fiil, sıfat, zarf, zamir, fiilimsi gibi pek çok kelime çeşidinden kurulur ve örnekleri boldur (Ergin, 2013: 377). Gagauz Türkçesinde de yaygın olarak kullanılan bir ikileme türüdür.

aar-aar "ağır ağır”(KK. 28), aaz-aaza "ağız ağıza" (GRRS), adım-adım "yavaşça; adım adım, yavaş yavaş" (GRRS, GD. 108, GTASGSV), alan-alan "1. sıra hâlinde, gruplar hâlinde. 2. şurada burada, düzensiz" (GRRS), alay-alay "gruplar hâlinde, grup grup, adacıklar hâlinde" (GRRS), annat annat (GTG. 196), asirdän asirä "asırdan aşıra" (GTASGSV), auç-auç "avuç avuç" (SS. 134, GY. 168), avşam-avşam 
"akşam akşam" (GTTIFÇK. 42), ayrıç ayrıç "ayrı ayrı" (GY. 168), azar-azar "azar azar" (GRRS, GTG. 101), başka-başka (GRRS), biyaz-biyaz "beyaz beyaz" (GTASGSV), bölük-bölük "parça parça, dizi dizi" (KK. 131), buunuk buunuk "boğunuk, boğunuk" (KK. 144), clvll clvıl (GÇŞA. 20), çabuk-çabuk "aceleyle" (GRRS), çekişe çekişe "çekişerek" (GHT. 138), çeşnä-çeşnä "1. çeşit çeşit. 2. ilginç ve ilgi çekici bir şekilde, değişik değişik" (GRRS), çeşni çeşni "çeşit çeşit" (GHT. 138), çıkım-çıkım "küçük küçük bölümler hâlinde, adacıklar şeklinde; düzensiz olarak, dağınık bir şekilde, gayri muntazam, burada ve orada" (GRRS), çile çile "demet demet" (GY. 168), çok-çok "uzun-uzun" (KK. 101), çürük-çürük (GÇŞA. 68), daar daar "dar dar" (GÇŞA. 298), dara-dar "zar zor, güçlükle" (GRRS), dalga-dalga "1. kıvrımlı (saç) (SS. 56). 2.yığın hâlinde, arka arkaya" (SS. 127), damna-damna "damla damla" (SS. 3), deste deste (GY. 171), dik-dik "ters ters" (KK. 67), dikiş dikiş (SS. 135), dilim-dilim "parça parça" (GTASGSV), dizi dizi "sıra hâlinde" (GRRS), dizim dizim "dizi dizi" (GD. 119), dünya dünya (GHT. 140), emen-emen "hemen hemen" (GTG. 196, MÇGRS. 209), erken-erken (SS. 231), erli-erinä "yerli yerine" (SS. 3), geniş geniş (GTSYDEÜBD. 230), göz-gözä (GD. 157), gözäl gözäl "güzel güzel" (GTG. 196), halka halka (GHT. 162), havalı havall (GY. 171), haylaz-haylaz "haylazca" (KK. 152), hemen-hemen "1. an be an; zar zor, en kısa sürede. (GRRS) 2. az kalsın, yaklaşı (MÇGRS. 220), hep-hep "her zaman" (GÇŞA. 43), hizlı hızlı (ÇTLEK. 154), hop hop "1. ziplamak. (SS. 242) 2. hoppa" (GY. 170), iiri-iiri "eğri eğri” (KK. 107), ilin-ilin "hafif hafif, rahatça, sıkıntısız bir şekilde" (KK. 135), kadem kadem "adım adım" (GD. 119), kale kale (GHT. 165), karşı-karşı "karşı karşıya" (GÇŞA. 39), kat-kat "katmanlar hâlinde, kat kat" (GRRS, GTTIFÇK. 208, GHT. 160), kesnik-kesnik "kesik kesik, aralıklı" (KK. 116), kllıç-kılıca (GD. 167), kipım-kıpım "an an, parça parça" (GTASGSV), kısım-kısım "bölüm bölüm" (SS. 71), klzgın kızgın (ÇTLEK. 162), koyu-koyu (GÇŞA. 153), kucak-kucak "kucak dolusu, bol bol, büyük miktarda" (GRRS), lüle lüle (GY. 166), may-may "neredeyse, az kalsın" (GRRS), nokta nokta (SS. 142), oylum oylum (GY. 158), páçka-páçka "deste deste, tomar tomar, yığınla; paket paket, koli koli" (GRRS), parça parça "1. "parçalar hâlinde, parçalanmış bir durumda (GGRS, GTASGSV, GD. 173). 2. azar azar" (KK. 269), pekpek "çok çok" (KK. 133, GDG. 61), pirll pırıl (SS. 73), sapa sapa "merkezden uzak" (GT. 196), sayfasayfa (SS. 54), sendel-sendel "bir yandan diğer yana sallanarak" (GRRS), sert sert "sert sert, öfkeli bir biçimde" (KK. 269), sık-sık "sıklıkla, çok sık" (GRRS, GTÇAUSÜ. 350), sıra-sıra (VUHŞŞS. 62, GY. 180), sürü-sürü "pek çok; grup olarak" (GRRS), şen-şen "neşeli ve mutlu bir biçimde" (KK. 55, GDG. 54), taman-taman "tam, tıpk1, tam olarak aynı" (GRRS), tay-tay "tay tay durmak deyiminde geçen bir söz" (GÇŞA. 86), tel-tel (SS. 193), tekrar- tekrar (MÇGRS. 275), tenä-tenä "1. tane tane, teker teker. 2. azar azar, küçük ölçülerle" (GRRS), tepä-tepä "tepe tepe" (GTG. 196), testä-testä "deste deste, dizinler, yığınlar hâlinde" (GRRS), tez-tezä "hemen" (GTG. 213), top top (GY. 170), trofa trofa "parça parça, kırıntıyla" (GÇŞA. 250), tunuk tunuk "donuk donuk; bulanık" (GTAÖM. 14, GD. 159), türlü-türlü "çeşit çeşit, her türlü” (GRRS, VUHŞŞS. 62, GDG. 28), ulam-ulam (GÇŞA. 54), uzun-uzun "uzunca bir süre" (KK.70, GDG. 40), üüsek-üüsek "yüksek yüksek" (KK. 153), yara-yara "yara, dert, üzüntü anlamında" (GTG. 207), yavaş-yavaş "yavaş bir biçimde; dikkatlice; azar azar; gitgide" (GRRS, KK. 261), yongayonga "kamga kamga" (GTASGSV), yudum-yudum "azar azar" (SS. 62, GTASGSV), zor-zor "büyük zorluklarla, güçlükle, çok zor" (GRRS, MÇGRS. 293)

\section{Yakın ya da Eş Anlamı İki Sözcüğün Yinelenmesiyle Kurulan İkilemeler}

Bu gruptaki ikilemelerde anlamlar birbirine yakın ya da eş olsa da sözcükler farklıdır. Eş anlamlı ikilemelerde sözcükler, asıl tekrarlardaki gibi her zaman birbirinin yerine kullanılamamaktadır (Hatiboğlu, 1981: 58). Aynı anlama sahip iki farklı sözcükten oluşan ikilemelerin amacı anlamı veya düşünceyi pekiştirmektir (Ağakay, 1954: 103; Özkan, 1996: 197).

Ağakay (1954: 104), yakın anlamlı sözcüklerle kurulan ikilemeler için "kavram çerçevesini genişletmeye yarar." ifadesini kullanmıştır. Bu ikilemelerde her sözcük ayrı bir anlama sahiptir. Anlam açısından ayrı fakat yakın çağrışıma sahip sözcüklerin birlikte kullanılması sonucu oluşan ikileme ile ortaya çıkan anlam kavram alanını genişletir. Ayrıca yakın anlamlı ikilemelerin bazıları anlam yanında ses ve biçim yakınlığına da sahiptir (Hatiboğlu, 1981: 58). Buna Gagauz Türkçesinden aba-şuba, ayın$a c ̧ ı$, tuz-buz vb. tarzdaki ikilemeler örnek verilebilir. Gagauz Türkçesinde yakın ya da eş anlamlı sözcüklerle kurulmuş ikilemeler şu şekildedir:

aaç-susuz "aç susuz" (GTTIFÇK. 42, GD. 104), aba-şuba "aba kürk" (GTG. 197), açlık-yokluk (GTG. 197), arada-saatta "bkz. arada sirada" (GRRS), arada-sirada "bazen, zaman zaman, ara sira" (GRRS), ara-sıra "bkz. arada-sırada" (GRRS), ayın-açık "herkesin gözü önünde; ayan beyan, apaçık" (GRRS), bayırlar-daalar "bayırlar dağlar" (SS. 7), bobadan-dedelerdän "babadan dedelerden, atalarından" (GTTIFFCK. 84), bobadan-oola "babadan oğula" (GTTIFÇK. 177), candan-ürektän "candan 
yürekten" (GTTIFFÇK. 83), cat-eni "yeni” (GTG. 197), çair-çimen "çayır çimen" (VUHŞŞS. 62), çatlakpatlak "çatlak patlak" (KK. 224, G. 119), dağlar-taşlar (GHT. 170), darya deniz "derya deniz, uzaklık, genişlik" (GTAÖM. 11), delimdeşik "delik deşik" (GRRS), dört-beş (GTG. 206), düz-dooru (GTG. 197), ekmäk-şıra "ekmek ve tatlı" (SS. 255), emiş-meyva "yemiş meyve" (GTASGSV), er-toprak "yer toprak" (GTG. 197), eşinä-karısına (GD. 100), fabrika-zavod (GTG. 197), gram-drem "gram dirhem" (GRRS), gül tomruk "gül tomruk" (GTAÖM. 14), gül-çiçek (GTG. 197), gül-yaprak (GÇŞA. 260), gün-güneş (GÇŞA. 116), gün-ömür "gün ömür" (KK. 75), güz-klş (SS. 92), hacı-hoca (GHT. 145), halımı-hatırımı "hâlimi hatrımı" (GD. 151), havada-bulutta (SS. 28), harç-borç (GASÜBD. 1183), ilin yavaş "hafifçe ve yavaşça" (SS. 63), ilk-seftä "ilk sefte" (GTG. 197), insannar-karımcalar (GTTiFÇK. 161), kardaşklzkardaşları "kardeşi ve kız kardeşleri" (SS. 255), karpuz-kaun "karpuz kavun" (GÇŞA. 60), kaun karpuz "kavun karpuz" (GTASGSV), kavga-çekiş (GÇŞA. 19), kır-bayır "kır bayır" (GRRS), kız-çocuk (GÇŞA. 18), kir-kihlä (GTG. 197), konu-komşu "tüm komşular, tanıdıklar" (GRRS), konuş-şennik "eğlence şenlik" (GD. 111), kör-sakat (GTG. 197), kutlu-kademli "kutlu mutlu" (GHT. 105), nasll-nesoy (GTG. 197), nastnica (GTG. 197), Oğuz-Göktürk (GTTIFFÇK. 180), Oğuz-Türk (GTTIFÇK. 41), okumaa-yazmaa "okuma yazma" (GD. 100), pak-duruk (SS. 100), nışan-minunya "nişan mucize" (SS. 143), saar-dilsiz "sağır ve dilsiz" (GRRS), saa-salim "sağ salim, zarar görmeden" (GRRS), saa-selem "bkz. saa salim" (GRRS, KK. 75), saa-sem "bkz. saa selem" (GRRS), saalık-klsmet "sağlık mutluluk" (SS. 159), sazdan-samandan (GTG. 197), sedef-altın (SS. 77), sır-yalan (SS. 197), sıra-dizi (GTASGSV), soruş-cuvap "soru cevap" (GRRS), soy-sense "soy-aile, sülale" (GTASGSV. 6), soy-sop "bütün soy ve hisımlar"(GRRS), şölä-bölä "şöyle böyle" (GRRS), ter-su (GTG. 197), toz-duman "toz duman" (GÇŞA. 126), tölä-bölä "şöyle böyle" (GRRS), tuz-biber (GHT. 157), tuz-buz "paramparça" (GRRS, VUHŞŞS. 62), tuz-ekmek "ekmek ve tuz" (GRRS), tuz-sabun (GTTIFÇK. 148), uçsuz-kenarsız "uçsuz bucaksız" (GTS. 66, SS. 49), yalan-falş "yalan sahte" (KK. 29), yari-yavklusu "yâri yavuklusu" (GD), yazl-çizi (GTG.197), yorgan-döşek (VUHŞŞS. 62), zar-zor "1. ister istemez. 2. güçlükle" (GRRS, GD. 143)

\section{Zıt Anlamlı İki Sözcüğün Yinelenmesiyle Kurulan İkilemeler}

Anlamca birbirine zıt iki sözcüğün tekrarıyla oluşan ikileme çeşididir. Burada da ikilemeyi oluşturan sözcükler birbirinden farklıdır. Zıt anlamlı ikilemeler, bağlama ya da beraber kullanıldığı sözcüğe farklı anlamlar katarlar. Ağakay'a göre (1954: 104), bunların bir kısmı diğer ikilemeler gibi yeni bir kavram meydana getirir (öte beri, alt üst). Bir kısmı kavramlar arasında kutuplaşmaya sebep olarak birbirine karşı1 iki düşünceyi anlatır ( $y a z$ klş, gece gündüz). Bir kısmı ise ihtimal dâhilinde olan iki kavramı karşılaştırıp anlama kararsızlık, tereddüt gibi durumlar yükler (var yok, az çok, ileri geri). Ayrıca bu tür ikilemeler birlikte kullanıldığı sözcügün miktar, zaman ve durum açısından sınırlarını belirlemeye yarar (Hatiboğlu, 1981: 59). Gagauz Türkçesindeki zıt anlamlı ikilemeler arasında sözü edilen özelliklere sahip örneklerle karşılaşılmaktadır.

acı-tatlı (GTG.197), ana-boba "1. ana baba, ebeveynler. (GRRS, GTAÖM. 10) 2. doğumsal, yerli (doğduğu yer hakkında)" (GRRS), aşaa-yukarı "aşağı yukarı"(KK. 243), avşam-sabaa "akşam ve sabah" (GRRS), az-çok "az çok, bir miktar" (GRRS, GTG. 131), bayır-çukur (GTG. 197), büün yarın "bugün yarın” (GTYYÜ. 94), büü-küçüü "büyüğü küçüğü” (SS. 147), dost-duşman "dost ve düşman” (GRRS), düşüp kalkıp (GTG. 175), er-gök "yer gök" (GÇSA. 69), ileri-geeri "ileri geri” (GRRS, KK. 179), gecägündüz "gece gündüz, sürekli" (GRRS, VUHŞŞS. 62), gelin-güvee "gelin güveyi” (GY. 138), gündüz-gecä (GÇŞA. 154), götürmeyä-getirmeyä "götürüp getirmeye" (KK. 222), helal haram (GTG. 209), kara-biyaz "kara beyaz” (SS. 8), kart-koca (SS. 136), kış-yaz (GTG. 210), küçüü-büü "büyügü küçügü̈” (GTG. 197), ötää-beeri "az buçuk, biraz; hafifçe, hafif tertip; gelişigüzel, üstünkörü; şöyle böyle" (GRRS), ötääbuyanı "öteye beriye" (GRRS), şaş-beş "şaş beş, şaşırmak anlamında" (GRRS), tatll-acı (GTG. 197), uzak-yakın (GTASGSV), yukardan aşaa "yukarıdan aşağıya" (GRRS)

\section{Biri Anlamlı Biri Anlamsız İki Sözcüğün Yinelenmesiyle Kurulan İkilemeler}

$\mathrm{Bu}$ gruptaki ikilemelerde anlamlı sözcüğün genellikle önce kullanıldığı görülür. Anlamsız sözcüğün birinci unsur olarak yer aldığı bazı ikilemeler de mevcuttur. Hatiboğlu, ikilemeyi oluşturan unsurlardan ya birincisinin ya da ikincisinin tam anlama sahip olduğunu, öteki sözcüklerin de yarı anlamlı sayılabileceğini belirtir. Bu sebeple anlamsız sözcükleri anlamlı sözcüğün gölgesi olarak niteleyen Hatiboğlu, gölge sözcüklerin anlamı güçlendirmede rol aldığını ifade eder. Yani bu sözcükler, anlamlı sözcügün gölgesinde tam olmasa da yarı anlam kazanmaktadır.

Hasan Eren (1949: 283), bu tür ikilemelerin eş anlamlı sözcüklerin azlığından dolayı birinci unsura yeni şekillerin eklenmesi suretiyle oluşturulduğunu, ikinci unsur olan yeni şeklin de ağızlarda ayrı ve 
anlamlı bir kelime olarak kullanıldığını belirtmiştir. Bu durumda Eren'e göre anlamlı sözcük ilk unsurda yer almaktadır. Gagauz Türkçesi ikilemelerine bakıldığında anlamlı sözcügün çoğunlukla başta bulunduğu görülmektedir.

aykırt-buykuru "eğri büğrü" (GRRS), can-cun "herhangi bir kimse" (GRRS, GDG. 33, KK. 260), cenk-benk (GTG. 198), çatak-matak (GTG. 197), draku-mraku (GTG. 197), eyri büyrü "eğri büğrü" (GHT. 160), geç meç (GTTiFÇK. 25), gezeta-mazeta (GTG. 197), gırklaya-mırklaya (GTG. 197), harçaparça "bkz. parça-parça" (GRRS), iiri-büürü "eğri büğrü" (GRRS), iş-miş (GTG. 197), pala-parta "pıl1 pırt1, paçavra" (GRRS, KK. 209), parçadan-purçadan (GTG. 198), senek-benek (GY. 166), teker-meker (GTG. 197), türlü-bürlü "bkz. türlü-türlü" (GRRS), ufak-tüfek "ufak tefek" (KK. 56), yamru yumru (GY. 184)

\section{Anlamsız İki Sözcüğün Yinelenmesiyle Kurulan İkilemeler}

$\mathrm{Bu}$ ikilemelerde her iki sözcüğün de tek başına bir anlama sahip olmadığı fakat beraber kullanıldıklarında bir anlam ifade ederek anlatımı pekiştirdikleri görülür. Hatiboğlu (1981: 59), bu tür ikilemeleri "İki Sözcüğü de Yarı Anlamlı İkileme" başlığı altında değerlendirmiş ve anlama sağladıkları katkı açısından tamamıyla anlamsız sayılamayacaklarını belirtmiştir. Gagauz Türkçesinde anlamsız iki sözcügün yinelenmesi sonucu kurulan ikileme örnekleri şöyledir:

alak-bulak "allak bullak, karmakarışık, darmadağın, alt üst" (GRRS, KK. 95) , çatra-patra "1. anlaşılmaz bir şekilde, geveleyerek konuşma için kullanılır. 2. bozuk bir dille, dikkatsiz bir şekilde konuşmayı anlatmak için kullanılır" (GRRS), filan-pişman "1. filanca. 2. bu ve şu; falan" (GRRS), filanfişman "felan filan" (GTG. 198), satta patta "sat pat, orada burada, baz1 yerlerde" (KK. 269), tır-mır "bir şekilde" (GRRS)

\section{Yansıma Sözcüklerin Yinelenmesiyle Kurulan İkilemeler}

Yansımalar, doğadaki seslerin taklidine dayanan ve çoğunlukla ikileme biçiminde kullanılan sözcüklerdir. Yansıma sözcüklerle kurulan ikilemeler, bir önceki başlık içerisinde de değerlendirilebilir. Çünkü yansımaların çoğunda her iki unsur da tek başına kullanılamamakta ve bir anlam bildirmemektedir. Hatiboğlu (1981: 35), bu ikileme türü için "Doğanın seslerini taklit eden, yansıtan ve çok defa yalın durumda kullanılan yansımalar ya aynı sözcükten ya ses ve yapı bakımından birbirlerini andiran sözcüklerden kurulur." demektedir. Gagauz Türkçesinde tespit edilen yansıma sözcüklerin tekrarına dayalı ikilemeler daha çok aynı sözcüklerden kurulmaktadır.

bangır bangır "yüksek sesle" (GTG. 179), cangır-cıngır "bu biçimdeki gürültü taklidi" (GRRS), cangır-cungur "bkz. cangır-cıngır" (GRRS), cıngır cıngır "cangıl cungul" (GTG. 179), clvıl cıvıl (GÇŞA. 20), ciu-ciu "bkz. civ-civ" (GRRS), civ-civ "1. civcivlerin çıkardığı taklidi ses. 2. c1vıldamak, ötmek" (GRRS), çat-pat "1. şöyle böyle, ötede beride, şurada burada. 2. az, biraz, bir miktar. 3. zaman zaman, kimi vakit, ara sıra, bazen, bazı bazı" (GRRS), çatır-çatır "çatırtıyı taklit eden ses" (GRRS, GTG. 179, VUHŞŞS. 62), çır-çır "cırcır böceğinin ses taklidi”" (GRRS), çıtır-pıtır (GRRS), çıt-pıt (GRRS), çıt-çıt (GRRS), çıtır-çıtır "gevrek bir şey yenilirken, kömür, odun yanarken, ince çubuklar kırılırken çıkan ses" (GRRS), çin-çin "çınlamayı taklit eden bir ses" (GRRS), çur çur "su sesinin taklidi” (GRRS), damba dumba "trampet sesi" (GRRS), dumba-dumba "trampet sesi" (GRRS), dum-çık "bkz. dumba-dumba" (GRRS), dum-dum "bkz. dumba-dumba" (GRRS), fikır-fikır "kaynayan su ve benzeri şeylerin sesini ifade etmek için kullanılır", fis-fis "tıslamayı taklit eden ses" (GRRS), fis-fis "fis fis" (MÇGRS. 213), fiş-fiş "hışırtıyı taklit eden ses" (GRRS), fişır-fişır "bkz. fış-fış" (GRRS), gak-gak "karganın çıkardığı ses" (GÇŞA. 369), gicır-gıcır "gıcırtı" (GRRS), girt-girt "gıcırt1, taklidî ses" (GRRS), girts-gırts "keman gıcırtısının taklidi" (GRRS), goţi-goţi "domuzları çağırmak için kullanılır" (GRRS), gür-gür "gök gürlemesi" (MÇGRS. 217), harp-harp "otlama sesinin taklidi” (GTG. 179), hop-zup "hop zip" (GÇŞA. 46), kıs-kıs "sessiz bir biçimde gülmeyi anlatır" (GRRS), kıtır-kıtır "gevrek bir ses çıkararak" (GRRS), kuş-kuş "koyunları çağırmak için kullanılan ünlem" (GRRS), kürt-kürt "yansıma ses" (MÇGRS. 245), kütküt "kalp atışı" (GRRS), lak-lak "bir leyleğin gagasını kullanırken veya hayvanların bir şey yerken ya da içerken çıkardıkları ses" (GRRS), läk-tık "toynakların takırdaması, atların toynaklarının taklidi" (GRRS), lap-lap "taklit için kullanılan bir söz" (GRRS), link-link "kelebeğin uçuşunun taklidi" (GRRS), mir-mır "1. mırıldanma sesi. 2. kedinin çıkardığı ses" (GRRS), lum-tum (GTG. 179), lupur-tupur "patırtıl1 gürültülü” (GTTIFÇK. 89), paldır-küldür (GHT. 129), patır-patır "ayak seslerini taklit etmek için kullanılır" (GRRS), pıtır-pıtır "adımların hafif vuruşunu taklit eden bir ses, hafif ayak patırtıları" (GRRS), pıt-pıt "keklik tarafından yayılan bir ses" (GRRS), pıti-pıti "bkz. pit-pıt", şapur şapur "şapır şupur" (GTG. 179), şarıl-şarll "bkz. şar-şar" (GRRS), şar-şar "su sesi”" (GRRS), şıpır-şıpır (GRRS), şırll-şırıl "su 
gürültüsü" (GRRS), tıkır-tıkır "herhangi bir nesnenin çıkardığ 1 taklidi ses" (GÇŞA. 399), tukur-tukur "yuvarlanan bir nesnenin çıkardığı ses" (GRRS, GHT. 160), tır-tır "cırcır böceği” (GRRS), vak vak "kazların çıkardığı ses" (GY. 166), vcik vcik (GTG. 179), zıga-zıga "keman sesi" (GRRS), zin-zin "cam sesi taklidi (çınlama, kırılma)" (GRRS)

\section{Kökenleri Bakımından İkilemeler}

İkilemelerde aynı veya farklı kökene sahip sözcükler bir araya gelebilir. Bu açıdan ikilemeler, tamamıla Türkçe ve yabancı sözcüklerden oluşabileceği gibi bir unsuru Türkçe, bir unsuru yabancı sözcüklerden de oluşabilir. Gagauz Türkçesindeki ikilemeleri kökenleri bakımından bu şekilde ele almak mümkündür.

\section{Türkçe Sözcüklerle Kurulan İkilemeler}

$\mathrm{Bu}$ grupta ikilemeyi oluşturan unsurların her ikisi de Türkçedir.

auç-auç "avuç avuç" (SS. 134, GY. 168), bü̈̈n yarın "bugün yarın" (GTYYÜ. 94), çatlak-patlak "çatlak patlak" (KK. 224, G. 119), delimdeşik "delik deşik" (GRRS), gelin-güvee "gelin güveyi” (GY. 138), gündüz-gecä (GÇŞA), kart-koca (SS. 136), iiri-iiri "eğri eğri” (KK. 107), kurt-kuş (GD. 144, GTTIFÇK. 73), sir-yalan (SS. 197), şen-şen "neşeli ve mutlu bir biçimde" (KK. 55, GDG. 54), tuz-ekmek "ekmek ve tuz" (GRRS) vb.

\section{Türkçe ve Yabancı Sözcüklerle Kurulan İkilemeler}

Gagauz Türkçesinde bir Türkçe unsur ile bir yabancı unsurun oluşturduğu ikilemelerde yabancı unsurun Arapça veya Farsça kökenli olduğu görülür. Farklı kökenlerden oluşan bu ikilemelerde Türkçe unsur genellikle önce gelmektedir.

al-pembä (Fa.) "al pembe" (ÇTLEK. 162), darya (Fa.)-deniz "derya deniz, uzaklık, genişlik" (GTAÖM. 11), emiş-meyva (Fa.) "yemiş meyve" (GTASGSV), harç (Ar.)-borç (GASÜBD. 1183), karabiyaz (Ar.) "kara beyaz" (SS. 8), kaun karpuz (Fa.) "kavun karpuz" (GTASGSV), saalık-kısmet (Ar.) "sağlık mutluluk" (SS. 159), soruş-cuvap (Ar.) "soru cevap" (GRRS), tuz-biber (Rum.) (GHT. 157) vb.

\section{Yabancı Sözcüklerle Kurulan İkilemeler}

Yalnızca yabancı sözcüklerden kurulan ikilemelerde, unsurlar ya aynı ya da farklı kökene sahiptir. $\mathrm{Bu}$ açıdan iki çeşit olan ikilemelerin Gagauz Türkçesinde, Arapça+Arapça ve Farsça+Farsça sözcüklerden kurulu olanları yanında Arapça+Farsça, Arapça+Rusça, Farsça+Rumence gibi çeşitli dillere ait sözcüklerden kurulu örnekleri de bulunmaktadır.

aba (Ar.)-şuba (Rus.) "aba kürk" (GTG. 197), dost (Fa.)-duşman (Fa.) "dost ve düşman" (GRRS), gram (Fr.)-drem (Ar.) "gram dirhem" (GRRS), hacı (Ar.)-hoca (Fa.) (GHT. 145), helal (Ar.) haram (Ar.) (GTG. 209), kör (Fa.)-sakat (Ar.) (GTG. 197), nışan (Fa.)-minunya (Rumn.) "nişan mucize" (SS. 143), sayfa (Ar.)-sayfa (Ar.) (SS. 54) vb.

\section{Yapı Bakımından İkilemeler}

\section{Hâl Ekleriyle Kurulan İkilemeler}

Hâl eklerini almış sözcüklerle de ikileme kurulabilmektedir. Gagauz Türkçesinde hâl ekleriyle kurulmuş ikilemelere sıklıkla tesadüf edilir. Hâl ekleri, ikilemeyi oluşturan unsurların bazen her ikisine bazen de sadece birine eklenmektedir. Bunun dışında her iki unsur aynı hâl ekini alabileceği gibi farklı hâl eklerini de alabilmektedir.

\section{Yalın Hâldeki İkilemeler}

Bu ikilemelerde her iki unsur da herhangi bir hâl eki almamıştır.

ayrıç ayrıç "ayrı ayrı" (GY. 168), başka-başka (GRRS), dağlar-taşlar (GHT. 170), güz-kış (SS. 92), saa-salim "sağ salim, zarar görmeden" (GRRS), saar-dilsiz "sağır ve dilsiz" (GRRS), sık-sık "sıklıkla, çok sık" (GRRS, GTÇAUSÜ. 356) vb.

\section{İlgi Hâli Ekiyle Kurulan İkilemeler}

Bu gruba giren ikileme örneklerinde ilgi hâli eki çoğunlukla her iki unsurda da yer almaktadır. Bunun dışında tamlama biçimindeki iki ikilemelede tabii olarak sadece ilk unsurda karşımıza çıkmaktadır. 
daymaların daymalarında "yüzyıllar boyunca, ebediyete kadar" (GRRS), güllerin gülü (SS. 5), kırın-daayın "kırın dağın" (SS. 67), küçü̈̈n-bü̈̈yün "küçügün büyüğün" (SS), şunun-bunun "kimliği belli olmayanın, adı sanı bilinmeyenin" (GRRS), topraan-gökün "toprağın göğün" (SS. 129)

\section{Yönelme Hâli Ekiyle Kurulan İkilemeler}

Gagauz Türkçesi ikilemelerinde yönelme hâli ekinin genel olarak ikinci unsura eklendiği görülür. Az da olsa ekin ilk unsura ya da her iki unsura getirildiği örneklerle de karşılaşılır. Bu hâl ekiyle kurulan ikilemelerde ilk unsur ya yalın hâldedir ya da ayrılma hâli ekini alır.

aardl-aardına "ardı ardına, aralıksız olarak" (KK.63), aaz-aaza "ağız ağıza" (GRRS), baş-başa "çok yakın, uç uca, yan yana. (GRRS) 2. yalnız, tek başına" (GÇŞA. 366), bitki-bitkiyä "eninde sonunda" (KKRSVÜBD. 33), boş-başına "yalnız başına" (GD. 113), bütün-bütünä "tamamen, bütünüyle" (GRRS), çalıya-çırpıya (GHT. 171), çata-çat (GTG. 197), gecedän geceyä (GTTIFFÇK. 83), gün-gününä "günü gününe, tam vaktinde" (GRRS), güreş-güreşä "güreş güreşe" (GD. 167), güüs-güüsä "göğüs göğüse" (GRRS), karşı-karşıya "yüz yüze, birbirine karşı" (GRRS, GD. 173), karşi-karşiya "1. karşı karşıya. 2. yüz yüze" (MÇGRS. 231), kendi-kendinä "yalnız, tek, kendi kendine" (GRRS), kılıç-kılıca (GD. 167), kolkola "el ele, omuz omuza" (GRRS, GTASGSV), kucak-kucaa "kucak kucağa" (GD. 110), raat-raadina (GTG. 197), saaya-sola "sağa sola" (SS. 81), şuna-buna "birine veya diğerine, başkalarına" (GRRS), uzun

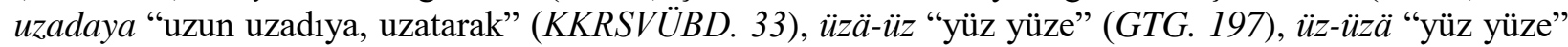
(SS. 163), yan yana "yan yana" (GTAÖM. 11), yarl-yarıya "yarı yarıya" (GRRS), ylldan-ylla (GTTİFÇK. 83), zamandan-zamana (GTTIFFÇK. 61), zor-zoruna "büyük zorluklarla, güçlükle, çok zor" (GRRS)

\section{Bulunma Hâli Ekiyle Kurulan İkilemeler}

Bulunma hâli ekiyle kurulan ikilemelere, yönelme ve ayrılma hâli ekine kıyasla daha az tesadüf edilmiş̧tir. Eldeki örneklerde ekin ikilemenin her iki unsuruna da eklendiği görülmüştür.

erdä-göktä "yerde gökte" (GTTİFÇK. 89), havada-bulutta (SS. 28), kar-klşında (GHT. 137), kurda bayırda (GY. 136), kırda-merada (GTG. 197), oyanda-buyanda "o yanda bu yanda" (KK. 221), şuradaburada "burada ve orada, birçok yerde" (GRRS), şurda-bırda "bkz. şurada-burada" (GRRS), uzaktauzakta (GÇŞA. 212)

\section{Ayrılma Hâli Ekiyle Kurulan İkilemeler}

Ayrılma hâli eki, ikilemenin ya ilk unsurunda ya ikinci unsurunda ya da her iki unsurun da olabilmektedir. Ancak ekin yalnızca ikinci unsura eklendiği örneklere diğer ikisine kıyasla daha az rastlanır. Ayrılma hâli ekinin ilk unsurda bulunduğu ikilemelerde ikinci unsur genellikle yönelme hâli ekini alır.

aariflerdän-aarif "ariflerden arif" (SS. 31), aaz-aazdan "bkz. aazdan-aaza" (GRRS), aazdan-aaza "ağızdan ağıza" (GRRS), açlıktan-yokluktan (GTTIFÇK. 149), arpadan boodaylardan "arpadan buğdaylardan" (GÇŞA. 50), asirdän asirä "asırdan asıra" (GTASGSV), baştan ayaa "baştan aşağı" (KKRSVÜBD. 33), baştan-başa "baştan sona; uçtan uca" (GRRS), birdän-birä "birdenbire, beklenmedik bir şekilde, aniden" (GRRS), biyaz biyazlardan "beyazlardan beyaz" (SS. 182), bobadan-dedelerdän "babadan dedelerden, atalarından" (GTTIFÇK. 84), bobadan-oola "babadan oğula" (GTTIFFÇ. 177), bobasindan-anasindan "babasından annesinden" (GD. 107), candan cana (GTASGSV), candan-ürektän "candan yürekten" (GTTIFÇK. 83), doorudan dooruya "doğrudan doğruya" (GRRS), doz-dolayından "her tarafından" (GAA. 115), el-eldän "el ele" (GÇŞA. 185), gün-gündän "gün günden, günden güne" (GRRS, KK. 144, MÇGRS. 217), günden güne (GY. 195), kırdan kira (GÇŞA. 39), kol-koldan "kol kola" (MÇGRS. 239), parçadan-purçadan (GTG. 198), primejdiyadan primejdiyaya "tehlikeden tehlikeye" (KKRSVÜBD. 33), saat-saattan "saat saatten" (KK.269), sabaadan-sabaaya "sabahtan sabaya" (GRRS), sabaadan avşamadan "sabahtan akşama kadar" (GRRS), sazdan-samandan (GTG. 197), siradan-siraya (KK. 270), tozdan-dumandan (G. 66), yll-yıldan "yıldan yıla" (KK. 165, SS. 153), yukardan aşaayadan "baştan aşağı" (GRRS)

\section{Belirtme Hâli Ekiyle Kurulan İkilemeler}

Tespit edilen Gagauz Türkçesi ikilemelerinde belirtme hâli ekinin her iki unsura eklendiği örneklerle daha fazla karşılaşılmıştır. Bu gruptaki ikilemelerde ordan-orayl "oradan oraya" $(K K$. 68$)$ ve orayl-burayı "oraya buraya" (KK. 154) örneklerinde hâl ekleri arasındaki görev değişikliğine bağlı bir durum olduğu gözlenmiştir. 
anayı-bobayl "anneyi babay1" (GÇŞA. 156), halımı-hatırımı "hâlimi hatırımı" (GD. 151), oyantbuyanı "öteye beriye" (GRRS), orayl-burayl "oraya buraya" (KK. 154), ordan-orayl "oradan oraya" (KK. 68), şunu-bunu "biri veya diğeri” (GRRS), üzümü-gözümü (GD. 123), üzünü-elini “yüzünü elini” (GD. 157), yazl-kışı "hem yaz hem kış" (GRRS)

\section{Vasıta Hâli Ekiyle Kurulan İkilemeler}

Son olarak vasita hâli ekiyle kurulan ikilemelerde ek, genellikle ilk unsur üzerinde bulunmakla beraber her iki unsur üzerinde ya da sadece ikinci unsur üzerinde bulunabilmektedir.

actylan tatllyl "aciyla tatliyı" (GTASGSV), anaylan-bobaylan "ebeveynleriyle" (GRRS), bobaylan ool "babayla oğul" (GY. 143), deriylän kemik "sadece deri ve kemik" (GRRS), geceynen gündüz "geceyle gündüz" (GY. 207), gelinnän güvää "gelinle güvey" (GTTIFÇK. 90), klş-yazın (GÇŞA. 156), omuzlanoтиza (GÇŞA. 408), şunnan-bunnan "biriyle, başka biriyle" (GRRS)

\section{İyelik Ekiyle Kurulan İkilemeler} almıştır.

İyelik ekleriyle kurulan ikilemelerde birinci unsur hangi iyelik ekini almışsa ikinci unsur da o eki

ahmakların ahmaasın "ahmakların ahmağısın" (GTTİFÇK. 32), ananı-bobanı "anneni babanı" (SS. 122), dedesi bobası "ataları" (GRRS), elleri-üzü “elleri yüzü” (SS. 231), gecesi-gündüzü (GTTIFÇK. 37), kaşın gözün (GY. 160), kimsin-neysin "kimsin nesin" (SS. 61), üstü başı (VUHŞŞS. 62), üzü-gözü (GTASGSV), yari-yavklusu "yâri yavuklusu" (GD. 126)

\section{Çokluk Ekiyle Kurulan İkilemeler}

Gagauz Türkçesinde çokluk eki +lar, +lär ve bu ekin ünsüz benzeşmesi sonucu oluşan + nar, + när biçimleri, ikilemelerin çoğu kez her iki unsuruna kimi kez de ikinci unsuruna eklenmiştir.

analar-bobalar "anneler babalar" (GY. 208), bayırlar-daalar "bayırlar dağlar" (SS. 7), dağlartaşlar (GHT. 170), gecelär gecelär (GÇŞA. 364), tepeler tepeler (GTAÖM. 11), toz-dumannar "toz dumanlar" (SS. 36)

\section{Yapım Ekleriyle Kurulan İkilemeler}

Gagauz Türkçesinde yapım ekleriyle kurulan ikilemeler önemli bir yer tutmaktadır. Gerek isim gerekse fiil kök veya gövdelerine getirilen çeşitli yapım ekleriyle ikilemeler kurulmaktadır. Görüldügü kadarıyla bir örnek dışında diğer ikilemelerde her iki sözcük de aynı yapım ekini almıştır.

$\mathrm{Bu}$ sahadaki ikilemelerin kuruluşunda yer alan yapım eklerinin neler olduğu sonuç kısmında belirtilmiştir.

açlık-yokluk (GTG. 197), analı-bobalı "analı babalı, ebeveynleri olan, bir ebeveyne sahip olmak anlamında" (GRRS), anasız-bobasız "anasız babasız, öksüz" (GRRS), ayaksız-elsiz (GÇŞA. 58), ayrıç ayrıç "ayrı ayrı" (GY. 168), belli-belersiz "belli belirsiz" (KK. 202), birär-birär "birer birer" (GD. 134), bölük-bölük "parça parça, dizi dizi" (KK. 131), burma burma (GY. 167), buunuk buunuk "boğunuk boğunuk" (KK. 144), cicili-bicili "süslü” (GRRS, GTS. 44), çürük-çürük (GÇŞA. 68), gölcük gölcük (GÇŞA. 307), güncääz-güncääz "gün gün" (GÇŞA. 67), havalı havalı (GY. 171), kesnik-kesnik "kesik kesik, aralıklı" (KK. 116), kıvrak-kıvrak (GTG. 196), kızgın kızgın (ÇTLEK. 162), konuş-şennik "eğlence şenlik” (GD. 111), küsülü küsülü (GTG. 196), oracık-buracık (GTG. 140), parçacık-parçacık "(GTASGSV), saalık-kısmet "sağlık mutluluk" (SS. 159), saatçaaz-saatçaaz "saat saat" (GÇŞA. 67), siracık-sıracık "sırayla, sıra sıra" (SS. 53), sonsuz-bitkisiz "sonsuz" (SS. 86), sürekli-sürekli "uzun süreli olarak" (SS. 174), sürücü̈k-sürücük (GTG. 196), şiirli-türkülü (SS. 45), uçsuz-kenarsız "uçsuz bucaksız" (GTS. 66, SS. 49), yudum-yudum "azar azar" (SS. 62, GTASGSV)

\section{Fiilimsi Ekleriyle Kurulan İkilemeler}

Fiil kök veya gövdelerinden yapım ekleri dışında fiilimsi ekleri kullanılarak da ikileme oluşturmak mümkündür. Gagauz Türkçesinde fiilimsilerin üç çeşidiyle de kurulmuş ikileme örneklerine rastlanmış ancak zarf-fiillerin daha fazla kullanıldığı görülmüştür. Fiilimsiler bazen aynı bazen de farklı sözcükler üzerine getirilmiştir. 


\section{Zarf-Fiil Ekleriyle}

Gagauz Türkçesinde, fiilimsiler arasında zarf-fiil ekleriyle kurulan ikilemelere daha sık rastlanır. Zarf-fiil çeşitlerinden özellikle $-a /-e /-\ddot{a}$ ekinin her iki unsura getirilmesi suretiyle oluşmuş ikilemeler oldukça fazladır. Bu ekin yanı sıra farklı zarf-fiil eklerini almış ikilemelerle de karşılaşılmaktadır.

aalaya aalaya "ağlayarak" (GTTIFÇK. 231), aldana-aldana "aldanarak" (KK. 75), annada annada "anlata anlata" (GTG. 173), annaşıllır-annaşılmaz "anlaşılır anlaşılmaz" (KK. 102), azıp-azıp (GÇŞA. 152), baara-baara "bağıra bağıra" (VUHŞŞS. 62, GASÜBD. 1176), baka baka "baka baka, bakarak" (GTAÖM. 12), başarır başarmaz "bitirir bitirmez" (GTTIFÇK. 234), çalarkan çalarkan "çalarken çalarken" (GTG. 196), çekişe çekişe "çekişerek" (GHT. 138), çevirdip çevirdip (GTG. 196), çüvüp çüvüp "zıplayıp zıplayıp" (VUHŞŞS. 62), damnaya-damnaya "damlaya damlaya" (GTASGSV, GHT. 139), diişe diişe "değiş̧e değişe" (GRRS), dinnenä-dinnenä "dinlene dinlene" (KK. 72), diiyär-diimäz "değer değmez" (KK. 211), dizä-dizä (GÇŞA. 68), dön-dönä (GTG. 196), dönä-dönä "dönerek" (GRRS, GDG. 66), dura-dura (GTTIFÇK .231), durup-durup "bekleyerek, durarak" (VUHŞŞS. 62, GTG. 175), duyulurduyulmaz "hissedilir hissedilmez" (KK. 248), düşä kalka "güçlükle" (GRRS), düşünä-düşünä "düşüne düşüne" (GÇŞA. 245), düşüp kalkıp (GTG. 175), dü̈̈şä-düüşä "dövüşe dövüşe" (GD. 174), geçä-geçä "geçtikçe" (GD. 130), geçir-geçmäz "geçer geçmez" (KK. 84), gele-gele (GD. 131), gelip-gelip (GD. 100 ), gidä-gidä “1. yavaş yavaş" (GRRS) 2. gidip dolaşarak, gezip görerek" (GTG. 173), gid-gidä "gitgide"(KK. 140), git-gidä "gitgide, azar azar, yavaş yavaş, gittikçe" (GRRS, KK. 155), güle güle "gülerek" (GHT. 160, GY. 166), homurdana-homurdana "homurdanarak" (GDG. 65), istär-istemäz "ister istemez, beğen ya da beğenme" (GRRS, KK. 218), işleyä-işleyä "işleye işleye" (GASÜBD. 1176), kanakana "doya doya, bol bol" (GRRS, GTAÖM. 11), kane kane "kana kana" (GD. 117), kokuşa kokuşa "koklaşarak" (GASÜBD. 1181), konuşa konuşa "konuşarak" (GASÜBD. 1181), olur-olmaz "1. en azından, ancak. 2. şüpheli, belli olmayan, belki" (GRRS, KK. 249), salına-salına "burada ve orada, farklı yerlerde, her yerde, her tarafta, dört bir yanda" (GRRS), sarsa-sarsa "sarsalayarak" (GDG. 67), sarsalaya-sarsalaya "sarsa sarsa" (KK. 68), seçe-seçe (GÇŞA. 315), sevä-beenä "severek beğenerek" (GÇŞA. 150), sevä-sevä "seve seve, memnuniyetle" (GRRS), sile sile "silerek" (GY. 160), sinä-sinä "gizli gizli, sinsice" (GRRS), soruştura soruştura "soruşturarak" (GTG. 173), söleye söleye "söyleye söyleye" (GASÜBD. 1176), susa-susa "susarak" (GÇŞA. 54), toplayıp-toplayıp (GTTIFÇK. 124), uça kaçına "uçarak ve kaçınarak" (GTG. 173), ura-ura "vura vura" (GTTiFÇK. 230), utana utana (GTG. 173), uunauuna "uğuna uğuna" (KK. 166), yona-yona "yonta yonta" (GÇŞA. 85), zeetlenir-zeetlenmäz "eziyetlenir eziyetlenmez" (KK. 209)

\section{Sıfat-Fiil Ekleriyle}

Tespit edilen Gagauz Türkçesindeki ikilemelerin kuruluşunda sıfat-fiil eklerinden yalnızca -an, -än eki yer almıştır. Bu ek ise zıt anlamlı sözcükler üzerine eklenerek yinelenmiştir.

gelän-geçän "1. gelen geçen. (GRRS) 2. gelen giden” (GTAÖM. 12, GD. 128, MÇGRS. 214), girän-çıkan "giren çıkan" (KK. 231)

\section{İsim-Fiil Ekleriyle}

İsim-fiill eklerinin üçüyle de kurulmuş ikilemeler tespit edilmiş olsa da bunların örnekleri oldukça azdir.

çaarış-baarış "çağırış bağırış, gürültüyle" (GRRS, GHT. 161), gidiş-dönüşs "gidiş dönüş" (GRRS), gidiş-geliş "bkz. gidiş-dönüş" (GRRS), imek-içmek "yemek içmek" (GHT. 168), okumaa-yazmaa "okuma yazma" (GD. 100)

\section{Çekimli Fiillerle Kurulan İkilemeler}

Aynı veya farklı iki fiilin çekimlenmesiyle oluşmuş ikileme örneklerine Gagauz Türkçesinde de rastlanmıştır. Bu ikilemeler, bildirme kiplerinden geniş zaman, görülen geçmiş zaman ve şimdiki zaman; tasarlama kiplerinden emir kipi, istek kipi ve şart kipi kullanılarak oluşturulmuştur. İkilemeyi oluşturan her iki unsurda genellikle aynı kip eki kullanılmakla beraber farklı kullanımlar da mevcuttur. Ayrıca bu gruptaki ikilemelerin bazısında birinci unsur - $p$ ve $d i k c ̧ a ̈$ zarf-fiil eklerinden birini almıştır.

annat annat (GTG. 196), ansırıp durdu "aksırıp durdu" (GTG. 175), barar-çarar "bağırır çağırı"” (GTG. 197), çatlaar-patlaar (GTG. 197), çık-gez “çık gez”(KK. 113), dön-döneriz (GTG. 196), eşerdikçä eşerer "yeşerdikçe yeşerir" (GTG. 173), geçer-uçar (GTG. 197), gelip-geçer (GÇŞA. 55), gelip geçärdim (GD. 117), gelir-gelişiniz (GD. 149), gidärsän-geleceklär (GTG. 215), gider-gider (GD. 144), geziy-geziy 
(GD. 147), gidiniz gidiniz (GY. 168), gidip-gelärsin (GÇŞA. 154), giindi kuşandl "giyindi kuşandı" (GTTIFÇK. 217), inana-inanmaz (GDG. 58), kazıdı kazıdı (GTG. 196), sararıp solacaksın (GHT. 166), sarılaim-sarmaşaim "sarılayım sarmaşayım” (GD. 149), sayarsan-sayacaklar (GTG. 215), siktıkça sıkarmış (GTG. 173), suuyup-terleer (SS. 64), uluma uluma (GY. 171), uyudum-uyandım (SS. 35), yat da иуи (GTG. 215)

\section{Bir eylemin olumlu ve olumsuzunun birlikte kullanılmasıyla oluşan ikilemeler}

Bu sahada bir fiilin olumlu ve olumsuz çekiminin tekrarıyla oluşan birkaç ikileme örneği de tespit edilmiştir. Bunların daha çok emir kipi ve görülen geçmiş zaman çekiminde olduğu görülmüştür. İkilemeyi oluşturan fiillerin birincisi olumlu, ikincisi olumsuz çekimdedir.

ağla ağlama (GÇŞA. 272), aalamaa-aalamamaa "ağlamak ağlamamak" (GTASGSV), bastımbasmadım (ÇTLEK. 159), inan inanma (GÇŞA. 272), kaldl-kalmadı (G. 36), sölemää-sölämemää "söylemek söylememek" (GTASGSV)

\section{Pekiştirme Yoluyla Kurulan İkilemeler}

Gagauz Türkçesinde pekiştirme amacıyla bir sözcüğün ilk ünlüsünden sonra $m, p, \quad r, s, \quad z$ ünsüzlerinden birinin getirilmesiyle oluşan tekrarlar yaygın olarak kullanılmaktadır. "z" ünsüzünün eklenmesiyle yapılan örneklerden anlaşılacağı gibi aslında burada "s"nin "z"ye dönüşmesi söz konusudur: doz-dolayindan (GAA. 115).

ap-aç "çok aç" (GTG. 197), ap-ak "apak, bembeyaz" (GRRS), ap-açık"1. çok açık, çok belirgin. 2. çıplak" (GRRS) , ap-ansızdan "ansızın, beklenmedik, ani, aniden" (GRRS), ap-ayık "tamamen ayı"” (GRRS), ap-aydınnık (GTG. 197), bezbelli "1. besbelli, oldukça açık, açık bir şekilde, aşikâr, bariz, anlaşılır, belli. 2. muhtemelen, belki, galiba, herhalde (GRRS)", bim-biyaz "bembeyaz" (GRRS), bom-boş (GÇŞA. 258), bom-boz (KKRSVÜBD. 33), çes-çevreye (GTG. 198), çez-çevrä "çepeçevre" (GTTIFFÇK. 33), çır-çıplak "çırılçıplak" (GTTIFÇK. 84), dip-diri "çok diri, çok canlı. 2. ham, sert, az pişmişs" (GRRS), dop-dolu "ağzına kadar dolu" (GRRS), dop dooru "dosdoğru" (GRRS), dos-dooru "doğrudan" (GRRS, MÇGRS. 205), doz-dolayından "her tarafindan" (GAA. 115), dup-duruk "dupduru"(GRRS), dübüdüz "1. dümdüz. 2. her yere" (GRRS), düm-düz "dümdüz" (GRRS, MÇGRS. 207), düp-düz "bkz. düpä-düz" (GRRS), düpä-düz "dümdüz, mükemmel" (GRRS), em-eşil "yemyeşil” (GRRS), ep-eni "yepyeni” (GRRS), epiz-eni "yepyeni" (GRRS), gepä-genç "çok genç" (GTG. 198), kap-kara "simsiyah, çok siyah" (GRRS, MÇGRS. 230), kam-kayıl (GTG. 197), karma-karışık "şaşkın; karışık, dağınık, belirsiz, anlaşılmaz" (GRRS, GTASGSV), kas-katı (GTG. 198), kıp-kızgın (GTG. 197), kip-kirli "kipkirli" (GRRS), kop-kolay "çok kolay" (GRRS), kos-koca "koskoca, çok büyük" (GRRS, SS. 101), kos-kocamiti "bkz. kos-koca" (GRRS), kup-kuru "kupkuru, çok kuru" (GRRS), mas-maavi "masmavi" (SS. 5), mos-mor "1. koyu kahverengi. 2. mavi mavi" (GRRS), pam-pak (GTG. 197), para-parça "paramparça" (MÇGRS. 257), sapsaa "sapasağlam, çok sağlam, canlı ve sağlıklı" (GRRS), sapa-saa "bkz. sap-saa" (GRRS, GTASGSV), sap-sarl "sapsarı, çok sarı" (GRRS, SS. 3), sep-sert "çok sert" (GRRS), sıp-sık " "çok dar, sımsıkı" (GRRS), sip-silmä "ağzına kadar dolu" (GRRS), sop-soluk "çok soluk" (GRRS), sup-suuk "sopsoğuk, çok soğuk" (GRRS), tap-taazä "taptaze" (SS. 29), tep-temiz "tertemiz" (SS. 193), up-uzun "upuzun, çok uzun" (GRRS), yam-yaş “çok 1slak" (GTASGSV), yap-yalabık (GTG. 197), yap-yalpaz (GÇŞA. 166)

\section{Yardımcı Fiil (İsim+Fiil) ile Kurulan İkilemeler}

Gagauz Türkçesinde bazı ikilemeler olmaa ve etmää yardımcı fiilleriyle beraber kullanılır. Bunların fiilsiz şekliyle kullanımına rastlansa da devamında bir fiilin veya yardımcı fiilin kullanımına ihtiyaç duyulur. Bu tarz ikilemelerin tamamlayıcı unsurları gibidirler. Çalışmada saptanan bu gruptaki örnekler aslında deyimleşmiş ikilemelerdir. Yardımcı fiil dışında başka bir fiilin getirilmesiyle kurulmuş tek ikileme örneği tespit edilmiş̧tir: tay tay durmaa (GRRS).

daram-peram olmaa "paramparça olmak" (GÇŞA. 357), delim-deşik olmaa "delik deşik olmak" (GTASGSV), kls-kls etmää "sessiz bir şekilde gülmek" (GRRS), göz-kulak olmaa "gözetmek, korumak" (GTTIFÇK. 145), para-parça etmää "paramparça etmek" (MÇGRS. 257), şaş-beş olmaaa "şaşırmak" (ÇTLEK. 159), tay tay durmaa "henüz yürüyemeyen bir bebeğin ayakları üzerinde durmasını anlatan bir deyimde geçen bir söz" (GRRS), tuz-buz etmää "paramparça etmek” (GRRS)

\section{Sözcük Türü Bakımından İkilemeler}

İkilemeler, her tür sözcükten kurulabilir. Bu başlık altında isim, sıfat, zamir, zarf, bağlaç ve ünlemlerden kurulan ikilemeler ele alınmıştır. 


\section{İsimlerle Kurulan İkilemeler}

İsim türünden sözcükler arasında renk, hayvan, sayı ve organ isimleriyle kurulanlar dikkati çekmektedir. Gagauz Türkçesinde sayı başta olmak üzere organ ve renk isimleriyle oluşturulan ikileme örneklerine daha çok tesadüf edilirken hayvan isimleriyle kurulan bir örnek tespit edilmiştir. Elbette bunların dışında isim türünden farklı sözcüklerle de ikileme kurulmaktadır.

\section{Sayılarla Kurulan İkilemeler}

Farklı ya da aynı sayıların tekrarıyla da ikileme oluşturulmaktadır. Sayılarla kurulan ikilemelerin genellikle küçük sayıdan büyük sayıya doğru sıralandığı görülmektedir.

beş-on (GTG. 134), bir-iki (GTTIFÇK. 78, GTASGSV), birär birär "birer birer" (GD. 134), birinikin "birer ikişer" (GTG. 124), dördär-beşär "dörder beşer" (GTG. 101), dört-beş (GTG. 206), edi-sekiz "yedi sekiz" (GTG. 134), iki-üç (GTG. 134), ikidä-birdä (GÇŞA. 231), ikişer-üçer (GY. 209), on-onbeş (GÇŞA. 242), on dört-on beş (GTAÖM. 7), onaltı-onedi "on altı on yedi" (GTTIFÇK. 23), ü̧̈ gün üç gecä (GTTIFÇK. 49), üçtä-dörttä (GÇŞA. 191)

\section{Renk İsimleriyle Kurulan İkilemeler}

$\mathrm{Bu}$ gruptaki ikilemeler, birbirine zit veya uyumlu renkler olan kara, beyaz, kırmızl, pembe gibi renkleri yansitan sözcüklerle kurulmuştur.

al-pembä "al pembe" (ÇTLEK. 162), biyaz-biyaz "beyaz beyaz" (GTASGSV), kara-biyaz "kara beyaz" (SS. 8), kirmızı-pembä "kırmızı pembe" (SS. 48)

\section{Hayvan İsimleriyle Kurulan İkilemeler}

Taranan kaynaklardan sadece bir örneği tespit edilmiştir.

kurt-kuş (GD. 144, GTTIFÇK. 73)

\section{Organ İsimleriyle Kurulan İkilemeler}

Bu gruptaki ikilemeler, organ isimlerinden özellikle baş, el, göz, ayak ve yüz sözcükleriyle kurulur.

ayaksız-elsiz (GÇßSA. 58), baştan ayaadak "baştan ayağa kadar" (GTG. 208), göz-gözä (GD. 157), göz kulak (GTG. 126), kaşın gözün (GY. 166), üzümü-gözümü (GD. 123), üzünü-elini “yüzünü elini” (GD. 157)

\section{Zamir Olan İkilemeler}

Zamir çeşitleriyle de türlü ikilemeler oluşturulur. Bunların bir kısmı aynı bir kısmı da farklı zamirlerin tekrarına dayanır.

sän-bän "sen ben" (GÇŞA. 51), şu-bu "biri ya da diğeri" (GRRS), oracık-buractk (GTG. 140), te-te "işte, bir şey gösterilirken kullanılan söz" (GTASGSV)

Kimä-kimä baaşladım (GÇŞA. 184)

Şuracıkta- buracıkta o yok. (GTG. 140)

Kimsin-neysin sän, uzak sevda? (SS. 61)

Çok yapêr onu-şunu. (GÇŞA. 93)

\section{Zarf Olan İkilemeler}

Gagauz Türkçesinde zarflardan kurulan ikilemelerin yanı sıra ad ve sıfatlardan kurulmuş zarf görevinde kullanılan ikilemelere sıkça tesadüf edilir. Bunların cümle içerisindeki kullanımları aşağıda örneklendirilmiştir:

Delim-deşik oldu güüdän. (GTASGSV)

Ne gezersin o yanı buyanı. (GTG. 135)

Zar-zor güderim hayvannarı. (GD. 143)

Kristina bulamêêr nedän tutunsun, buunuk buunuk baarêr. (KK. 68)

Trofa-trofa doyurdun. (GÇŞA. 250) 
Harp-harp otlarmışlar. (GTG. 196)

... ama bişey bulmayıp, kesnik-kesnik güldü. (KK. 116)

Nesoy-nezaman yapmaa düünü. (GTG. 212)

Andrey tuttu kızı kolundan, iiri-iiri adımnadı. (KK. 107)

\section{Sıfat Olan İkilemeler}

Gagauz Türkçesinde sıfatlarla kurulan ikilemeler de çok kullanılır. Bu ikilemeler bir ismin önünde kullanıldığında sıfat görevini üstlenir. Sıfatlarla kurulan ikilemeler, aynı ya da ayrı sıfatların, sıfat-fiil eki almış sözcüklerin tekrarından ve bir sıfatın çeşitli ünsüzlerle pekiştirilmesinden meydana gelmiştir.

Bir-iki siracık yazayım. (GTASGSV)

Gelän-geçän yolcuları bana sorasın. (GD. 128)

-Bilersin? -sordu bana al-pembä yanaklı arkadaşım. (ÇTLEK. 162)

Darıldı Kristinaya ufak- tüfek işlär için. (KK. 56)

Mas-maavi göklär hem parlak güneş. (SS. 5)

Hep çıkardılar daar daar yollar. (GÇŞA. 298)

Sapa-sapa sokaklardan yollandılar. (GTG. 196)

\section{Ünlemlerle Kurulan İkilemeler}

Duygular başta olmak üzere çeşitli hususları anlatmak için kullanılan ünlemlerle de ikileme kurulmaktadır. Gagauz Türkçesinde türlü ses ve durumları yansıtan ünlemlerin yinelenerek ikileme biçiminde kullanıldı̆̆ 1 örnekler şöyledir:

aho aho (GTG. 178), aman aman (GTG. 178), badi-badi "kazların çağrıldığ1 veya sürüldüğü ünlem" (GRRS), bıcl-bıcı "kazları çağırmak için kullanılan bir ünlem" (GRRS), bi-bi-bi "hindileri çağırmak için kullanılır" (GRRS), ça-heys ça-heys "arabacının öküzleri haydama sesi" (GY. 143), gık-gık "kazları çağırmak için kullanılır" (GRRS), helä-helä "hele hele, uyarma ve şaşırma anlatan bir söz" (MÇGRS. 220), hádi-hay! "yavaş yavaş" (GRRS), haydi haydi (GTG. 178), hay-höö (GTG. 178), hele hele (GHT. 160), hop-hop "halk oyunu oynarken çıkarılan ses; bir şeyin hızını arttırmak ve neşelendirmek için kullanılır" (GRRS), hopa hopa (GTG. 178), mırk-mırk "tavşanları çağırmak için kullanılır" (GRRS), ma mali "anneye sesleniş" (GTG. 179), maleley mali "bkz. ma mali" (GTG. 179), mini-mini "hindileri çağırmak için kullanılır" (GRRS), na! na! "gösterme ünlemi” (GTG. 180), nani nani (GTG. 178), ply-pıy "piliçleri çağırmak için kullanılan bir ses" (GRRS), pi-pi-pi "hindileri çağırmak için kullanılı»" (GRRS), pisi-pisi "bkz. pis-pis" (GRRS), pis-pis "kedileri çağırmak için kullanılır" (GRRS), ta-ta "keçileri çağırmak için kullanılan bir ünlem" (GRRS), tıgl-tıgl "keçileri çağırmak için bağırırken söylenir" (GRRS), vay vay (GTG. 178$)$

\section{Bağlaçlarla kurulan ikilemeler}

Gagauz Türkçesinde bağlaçlarla kurulan ikilemeler de önemli bir yer tutmaktadır. Bu sahada özellikle $b a \ldots b a$, hem...hem, ne...ne, ya...ya, a...a, ha ..ha karşılaştırma bağlaçları zit ve yakın anlamlı sözcükleri birbirine bağlayarak bir tekrar sağlamıştır: ba klş ba yaz (GTG. 182), ne biber ne patlacan (GHT. 151), ya bü̈̈n ya dün (GTG. 183) vb. Bu bağlaçlar sadece isim türünden sözcüklerle değil fiillerle de kullanılmıştır: ba olur ba olmaz (GTG. 182), hem sevindim hem aaladım (SS. 129) vb. Bunlardan başka aynı veya yakın anlamlı iki sözcüğün arasına nän, hem, dä ve Farsça $b a / b e$ sıralama bağlaçlarının girdiği ikileme örnekleriyle de karşılaşılmıştır: günnän-gün "her gün" (GTTiFÇK. 112), üz-be-üz "yüz yüze" (GRRS), yıl-ba-yll (GTG. 196) vb. Bunların diğer örnekleri şu şekildedir:

a yok a var (GTG. 182), ba sevinç ba kahır (GTASGSV), ba erdä ba yukarda (GÇŞA. 73), bü̈̈nnän büün "bugün, şu anda, şimdiki" (GRRS), diz-be-diz "yan yana" (GRRS), genä hem genä (GTG. 196), ha varsin ha yoksun (GTG. 182), ne gündüz ne gecä (GÇŞA. 73), ne yıldız ne dä ay (GTG. 212), ölä dä bölä dä "öyle de böyle de" (GTG. 137), tölä dä-bölä dä "şöyle de böyle de, hem şöyle hem böyle" (GRRS), ya sän beni, ya bän seni (GTG. 183), ya çekiç ya kerpeden "ya çekiç ya kerpeten” (SS. 234) 


\section{Dizilişi Bakımından İkilemeler}

Türkçede ikilemelerin dizilişi üzerine yapılan çalışmalar bu dil birliklerinin rastgele sıralanmadığını, ses ve hece özellikleri bakımından belirli bazı kurallara bağlı olduklarını göstermiştir. Buna göre ikileme dizilişlerinde ikilemeyi oluşturan unsurların hece sayısı, ünlü ya da ünsüzle başlamaları birer ölçüt kabul edilmiştir (Ağakay, 1954: 100-103; Tuna, 1983: 163-228).

Gagauz Türkçesinden tespit edilen ikilemeler de diziliş bakımından bu ölçütler esas alınarak incelenmiştir.

\section{Hece Sayıları Bakımından İkilemeler}

Az heceli kelimenin önce geldiği ikilemeler: Türkçede ikilemelerin dizilişinde hece sayısı az olan unsur genellikle başta yer alır (Ağakay, 1954: 101). Bu kuralın Gagauz Türkçesinde de geçerli olduğu görülür. Kural çerçevesinde tespit edilen ikileme örnekleri hece sayısı bakımından $1+2,1+3$ ve $2+3$ şeklindedir. $1+2$ şeklinde sıralanan ikilemeler diğerlerine göre daha fazladır.

aaç-susuz (GTTIFÇK. 42, GD. 104), al-pembä (ÇTLEK. 162), azbuçuk (GRRS), candan-ürektän (GTTIFÇK. 83), dost-duşman (GRRS), göz kulak (GTG. 126), gül tomruk (GTAÖM. 14), gün-ömür (KK. 75), ilk-seftä (GTG. 197), istär-istemäz (GRRS, KK. 218), kır-bayır (GRRS), kız-çocuk (GÇŞA. 18), saaselem "bkz. saa salim" (GRRS, KK. 75), sir-yalan (SS), soy-sense (GTASGSV. 6), tez-tezä (GTG. 213), tuz-ekmek (GRRS), uça kaçına (GTG), uçsuz-kenarsız (GTS. 66, SS. 49) vb.

Çok heceli kelimenin önce geldiği ikilemeler: Hece sayısı eşit olmayan ikilemelerde bir önceki başlıkta bahsedilen kuralın zıddı ile de karşılaşılabilir. Bu da çok heceli unsur az heceli olandan önce gelmesi demektedir. Ancak bunun örneklerine pek rastlanmaz. Örneğin; Mehmet Ali Ağakay (1954: 102), "Türkçede Kelime Koşmaları" adlı makalesinde hece sayısı birbirine denk olmayan 100 ikilemeden sadece 6 tanesinin kurala ters biçimde sıralandığını belirtmiştir. Gagauz Türkçesi ikilemeleri arasında bu şekilde dizilen beş örnek tespit edilmiştir.

ayaksı-elsiz (GÇŞA. 58), bayırlar-daalar (SS. 7), ileri-geeri (GRRS, KK. 179), kırmızı-pembä (SS. 48), yalan-fals (KK. 29)

İki unsuru da eşit heceden meydana gelen ikilemeler: İkilemelerin dizilişiyle ilgili diğer bir kural da eşit heceye sahip ikilemelerde ünlü ile başlayan unsurun önce gelmesidir (Ağakay, 1954: 102). Gagauz Türkçesinde bu kurala büyük ölçüde uyulduğu görülmüştür. Hatta Gagauz Türkçesinde "e" ünlüsü önünde "y" ünsüzünün kullanılmaması, söz konusu kuralın uygulanabilirliğini arttırmıştır. Zira, "emişmeyva", "er-gök", “üzümü-gözümü” şeklindeki ikilemeler Türkiye Türkçesinin ses özelliklerine göre kural dışı kalmaktadır.

acı tatlı (GTG.197), alak-bulak "allak bullak, karmakarışık, darmadağın, alt üst” (GRRS, KK. 95), alış veriş "alışveriş" (GTG. 177), ana-boba (GRRS, GTAÖM. 10), avşam-sabaa (GRRS), az-çok (GRRS, GTG. 131), ekmäk-şıra (SS. 255), emiş-meyva (GTASGSV), er-gök (GÇŞA. 69), eşinä-karısına (GD. 100), iiri-büürü (GRRS), ilin yavaş (SS. 63), Oğuz-Türk (GTTIFÇK. 41), ufak-tüfek (KK. 56), uzak-yakın (GTASGSV), üstün-körü/üstün-körün (GRRS, GDG. 31)

Bu kurala uymayan iki örnek saptanmıştır: birin-ikin (GTG. 124), bobadan-oola (GTTIFÇK. 177)

\section{Seslerin Durumuna Göre İkilemeler}

İki unsuru da ünlü ile başlayan ikilemeler: Bu grupta genellikle eşit heceli ikilemeler yer alır. Osman Nedim Tuna'nın eşit heceye sahip ünlü+ünlü yapısındaki ikilemelerle ilgili tayin ettiği kurala göre; ikileme unsurlarında başta veya içte yer alan ünlülerden sonra aynı ünsüzlerin gelmesi gerekir. Misal, azöz, ay-oy, az-uz; kem-küm, çatlak-çutlak, tek-tük vb. (1986: 169-170). Gagauz Türkçesinde ön ses açısından bu kurala uyan örneklere yalnızca aynı sözcüğün tekrarı ile oluşan ikilemelerde denk gelinmiştir: alay-alay (GRRS), üüsek-ü̈̈sek (KK. 153), ilin-ilin (KK. 135), ura-ura (GTTIFÇK. 230) vb. Bunun dışında ön ses için yakın, eş ya da diğer ögelerin tekrarıyla oluşan ikilemeler arasında kurala uyan örneklere denk gelinmemiştir. ayın-açık ikilemesinde her iki unsur ünlü ile başlamasına rağmen bahsedilen kurala uymamaktadır. (GRRS)

Tuna'nın verdiği örneklere benzer şekilde olan ve Gagauz Türkçesi için kuralı geçerli kılan örnekler iç seste, dolayısıyla ünsüz+ünsüz yapısındaki ikilemelerde karşımıza çıkmıştır: can-cun (GRRS, GDG. 33, KK. 260), cenk-benk (GTG. 198), çatra-patra (GRRS), paldır-küldür (GHT. 129), satta patta (KK. 269), tır-mır (GRRS), zar-zor (GRRS, GD. 143) 
Kuralın dışında kalan ve her iki unsuru da ünlü ile başlayan diğer ikileme örnekleri şunlardır: ayaksız-elsiz (GÇŞA. 58), erli-erinä (SS), üzünü-elini (GD. 157), üz-üzä (SS. 163)

İki unsuru da ünsüzle başlayan ikilemeler: Osman Nedim Tuna (1983: 170-171), eşit heceli olup ünsüz+ünsüz diziliminde olan ikilemelerde bazı değişmez ünsüz sıralar tespit etmiştir. Örneğin; "çıtı pıtı" ikilemesini ele alan Tuna, bu ikilemede ç harfinin alfabede p'den önce gelmesinden dolay1 "çıtı"nın ilk unsur olduğunu "pıtı"nın ise ikinci unsur olduğunu belirtmiştir. Tuna, bunu diğer benzer örnekler üzerinde uygulayarak değişmez bir ç-p sırası elde etmiştir. Gagauz Türkçesinde ç-p değişmez sırasına örnek teşkil eden 3 ikileme belirlenmiştir: çat-pat (GRRS), çatlak-patlak (KK, G. 119), çatra-patra $(G R R S)$

Tuna, bundan başka değişmez sıralar da belirlemiştir. Bunlar; ikileme başı, ortası ve sonunda olabilen $y-s, r-p, r-s, l-b, l-s, s-p, k-s, s-b$ dizilimindeki değişmez sıralardır (1983: 170-171). Gagauz Türkçesinde tespit edilen ikilemeler arasında hepsine olmasa da $l-s ̧, s s-b, r-s, s-p, c-b$ siralarına uyan örneklere denk gelinmiştir.

$$
\begin{aligned}
& \text { ş-b: şaş-beş (GRRS), şu-bu (GRRS) } \\
& \text { 1-ş: delimdeşik (GRRS) } \\
& \text { r-s: ara-sıra (GRRS) } \\
& \text { s-p: satta patta (KK. 269) } \\
& \text { c-b: cicili-bicili (GRRS, GTS. 44) }
\end{aligned}
$$

Bunlar dışında Gagauz Türkçesinde ünsüz+ünsüz yapısında olan diğer ikilemeler şöyledir: bü̈̈küçü̈ (SS. 147), çair-çimen (VUHŞŞS. 62), çatlak-patlak (KK. 224, G. 119), gram-drem (GRRS), güz-kış (SS. 92), hacı-hoca (GHT. 145), kaun karpuz (GTASGSV), saaya-sola (SS. 81), trofa trofa (GÇŞA. 250), yalan-falş (KK. 29) vb.

Birinci unsuru ünlü, ikinci unsuru ünsüz olan ikilemeler: Bu grup yukarıda "iki unsuru da eşit heceden meydana gelen ikilemeler" alt başlığında belirtilen kuralın örneklerini ihtiva eder. ana-boba (GRRS, GTAÖM. 10), arada-saatta (GRRS), avşam-sabaa (GRRS), emiş-meyva (GTASGSV), er-gök (GÇŞA. 69), iiri-büürü (GRRS), ilin yavaş (SS. 63), Oğuz-Türk (GTTIFÇK. 41), ufak-tüfek (KK. 56) vb.

Birinci unsuru ünsüz, ikinci unsuru ünlü olan ikilemeler: Son olarak bu grup ise bir önceki grupta bahsedilen kuralın zıddını veren örnekleri içerir. birin-ikin (GTG. 124), bobadan-oola (GTTIFÇK. 177)

Birinci kelimenin ilk hecesindeki ünlü sesin ikinci kelimede değiştirilmesiyle oluşturulan ikilemeler: can-cun (GRRS, GDG. 33, KK. 260)

Birinci kelimenin başındaki sesin ikinci kelimede değiştirilmesiyle oluşturulan ikilemeler: çatrapatra (GRRS), filan-pişman (GRRS), türlü-bürlü (GRRS)

Birinci kelimenin başındaki sesin değiştirilmesiyle oluşturulan ikilemeler: harça-parça (GRRS), senek-benek (GY. 166)

Gagauz Türkçesinde bazı ikilemeler zamanla kalıplaşarak birleşik kelime özelliği kazanmştır: alış veriş "alışveriş" (GTG. 177), azbuçuk "biraz" (GRRS), darmadaan "darmadağın olmuş. 2. yıkılmış" (GRRS), darmatura "harabe, yıkınt1, ören" (GRRS), dermetura "bkz. darmatura" (GRRS), dirdır (GRRS), hoşbeş "sohbet" (GRRS, GHT. 145), urdum-duymaz "vurdumduymaz" (ÇTLEK. 159), üstün-körü/üstünkörün "üstünkörü" (GRRS, GDG. 31), zırzop "zirzop, her işi aceleyle yapan kişi, ihmalkâr, özensiz. (GTS. 136. MÇGRS. 292) 2. savsak" (MÇGRS. 292), zigzag "zikzak" (GRRS)

Gagauz Türkçesinde ikilemelerin arasına başka sözcük ya da eklerin girdiği örneklerle de karşılaşılmıştır. Bunların daha çok cümle biçiminde olduğu görülmüştür. Araya giren sözcüklerin eş yakın ya da zıt anlamlı olması bir bütünlük sağlamış ve form olarak alışılmışın dışında bir ikileme türü meydana getirmiştir. biri geler biri gider (GASÜBD. 1178), bir-gevrek bir-yımışak (SS. 239), bir-ileri bir-geeri (SS. 232), bir däduylan bir babu (GTTïFÇK. 106), geçti güz geldi klş (GTG. 210), körpä mi genç mi (SS. 8), üç gün üç gecä (GTTİFÇK. 49) 


\section{SONUÇ}

Bu çalışmada, Türkçenin söz varlığında önemli bir yere sahip olan ikilemelerin Gagauz Türkçesindeki örneklerini ortaya koymak amaçlanmıştır. Aynı zamanda bunların kuruluşu ve belli başlı özellikleri gösterilmeyegayret edilmiştir. Bu sahadan derlenen ikilemeler yer yer Türkiye Türkçesi ikilemeleriyle karşılaştırmalı olarak da ele alınmıştır.

Herhangi bir dile ait sözlükler birçok konuyla ilgili önemli veriler sağlayan ve genellikle öncelikli olarak başvurulan kaynaklar olduğundan çalışmamızın birincil kaynağını "Gagauzça-Rusça-Romınca Sözlük" oluşturmuştur. Bu sözlükten 225, diğer 21 kaynaktan 424 ikileme tespit edilmiştir. Bu sayılara pekiştirme yoluyla kurulmuş olanlar ile bir ikilemenin çeşitli ekleri almış biçimleri de dâhildir. Birleşik kelime özelliği kazanan ikilemelerin sayısı ise 11'dir. Verilen rakamlar Gagauz Türkçesinin anlatımdaki gücünün, ikileme açısından sahip olduğu çeşitlilik ve zenginliğin somut delili sayılır.

Gagauz Türkçesinde tespit edilen toplam 649 ikileme anlam, yapı, köken, sözcük türü ve diziliş bakımından sınıflandırılarak incelenmiştir.

Gagauz Türkçesindeki ikilemeler anlam bakımından 6 grupta toplanmıştır. Bu gruplar arasında çoktan aza doğru bir sıralama yapıldığında aynı sözcüğ̈̈n yinelenmesiyle kurulan ikilemeler nicelik bakımından daha fazladır. Bunu yakın ya da eş anlamlı sözcüklerin yinelenmesiyle kurulan ikilemeler takip eder. Üçüncü sırada yansıma sözcüklerden oluşan ikilemeler yer alır. Fakat bu gruptaki ikilemelerin önemli bir kısmı aynı taklidî sözcüğün tekrarına dayanır. Yansımalı ikilemelerde läk-tık, çat-pat, dum-çık, hop-zup gibi iki unsuru farklı birkaç örnek vardır. Ayrıca tarama esnasında üçü bir hayvanın biri bir nesnenin taklidinden oluşan üçleme biçimindeki yansımalara da denk gelinmiştir: çın-çın-çın "saatin çıkardığı ses" (SS. 231), ga-ga-ga "kazların çıkardığı ses" (GRRS), vrak-vrak-vrak "ördeklerin çıardığ ses" (GÇŞA. 46), pış-pış-pış "salyangozun çıkardığı ses" (GÇŞA. 34). Geriye kalan üç başlık arasındaki sıralama ise zıt anlamlı iki sözcüğün, biri anlamlı biri anlamsız iki sözcügün ve anlamsız iki sözcügün yinelenmesiyle kurulan ikilemeler şeklindedir.

İkilemeler, başka bir düşünüşle yapıca aynı ya da farklı iki unsurun yan yana gelmesiyle oluşmuş dil birlikleridir. Çalışmada, Gagauz Türkçesinde isim ve fiil kök veya gövdelerinden kurulan ikilemeler yapı bakımından da incelenmiştir. Bunun sonucunda ikilemelerin kuruluşunda türlü eklerin görev aldığı görülmüştür. Çalışmanın bu kısmında ilk olarak hâl ekleriyle kurulan ikilemelere yer verilmiştir. Hâl eklerinin kimi zaman her iki unsura kimi zaman ise yalnızca bir unsura eklendiği gözlenmiştir. Misal, zamandan-zamana ikilemesi isim+ayrılma hâli eki / isim+yönelme hâli eki șeklinde kurulmuş, her iki unsurun da hâl eki aldığı bir ikilemedir. Formüle edilen şekildeki ikileme örneğine Gagauz Türkçesinde sık rastlanır. Bu örnekte her iki unsur da farklı hâl ekini almıştır. Buna diğer örnekler şu şekildedir: acıylan tatliyı (GTASGSV), daymaların daymalarında (GRRS). Her iki unsurun aynı hâl ekini aldığg örnekler daha fazladır: anaylan-bobaylan (GRRS), arpadan boodaylardan (GÇŞA. 50), candan-ürektän (GTTIFÇK. 83), erdä-göktä (GTTIFÇK. 89), kırın-daayın (SS. 67), saaya-sola (SS. 81), yazı-kışı (GRRS) $\mathrm{vb}$.

İkinci gözlenen durumda ise hâl ekleri ya sadece ikinci unsur üzerine "aaz-aaza (GRRS), bitki-bitkiyä (KKRSVÜBD. 33), kar-kışında (GHT. 137), klş-yazın (GÇŞA. 156), uzun uzadaya (KKRSVÜBD. 33)" уа da sadece birinci unsur üzerine aariflerdän-aarif (SS. 31), bobaylan ool (GY. 143), geceynen gündüz (GY. 207)" eklenmiştir. Diğer yandan bu grupta Türkiye Türkçesindeki şeklinden farklı oluşuma sahip ikileme örneklerine denk gelinmiştir. Örneğin; biyaz biyazlardan "beyazlardan beyaz" (SS. 182) şeklindeki ikilemede birinci ve ikinci unsur yer değiștirmiștir. aaz-aazdan "bkz. aazdan-aaza" (GRRS) ikilemesinde de aynı durum söz konusu gibi gözükmekle birlikte yönelme hâli eki alması gereken unsur eksiz bırakılmıştır. Bir bakıma yönelme hâli yerine yalın hâl kullanılmıştır. Gagauz Türkçesinde hâl ekleri arasındaki görev değişikliği ikilemelerde de kendisini göstermiştir. Aşağıda verilen dört ikilemedeki işaretli kısımlarda yönelme hâli eki yerine ilk ikisinde yükleme hâli eki, son ikisinde ayrılma hâli eki kullanılmıştır: ordan-orayı "oradan oraya" $(K K .68)$, orayı-burayı "oraya buraya" $(K K .154)$, el-eldän "el ele" (GÇŞA. 185), kol-koldan "kol kola" (MÇGRS. 239) vb. Son olarak kuruluşunda hâl eklerinin rol aldığı ikilemeler içerisinde yönelme ve ayrılma hâli ekini alanlar çoğunluğu oluşturmaktadır.

Hâl eklerinden başka her iki unsurun çokluk veya iyelik eklerinden birini aldığı ikilemelerle de karşılaşılmıştır. bayırlar-daalar (SS. 7), kaşın gözün (GY. 166), üzü-gözü (GTASGSV) vb.

Gagauz Türkçesinde türemiş isimlerden meydana gelen ikilemeler azımsanmayacak miktardadır. Türlü yapım ekleri kullanılarak oluşturulan bu ikilemeler, isimden türeyenler ve fiilden türeyenler olmak 
üzere iki çeşittir. İsimden türetilen ikilemelerde $+l l,+l ı k /+l u k /+n \imath k,+s l z,+a r /+e r,+c \imath k /+c u ̈ k,+$ cääz yapım ekleri, fiilden türetilen ikilemelerde $-m a,-c ̧,(l) m,-(l) s ̧ /-(i) s$, , -gın, $-a k,-(l) k$ yapım ekleri görev almıştır. Her iki unsura da aynı yapım eki eklenmiştir. Birinci ve ikinci unsurun farklı yapım ekini aldığı bir örnek belirlenmiştir: belli-belersiz (KK. 202). Bundan başka yapım ekinin sadece birinci unsura eklendiği bir örneğe denk gelinmiştir: saalık-klsmet (SS. 159)

Gagauz Türkçesinde fiil kök veya gövdelerine getirilen fiilimsi ekleriyle oluşturulmuş ikilemeler içerisinde zarf-fiillerle kurulanlar çoğunluğu oluşturmaktadır. Zarf-fiil eklerinden de özellikle $-a /$-e/-ä ekini alan ikileme örneklerinin fazlalığı göze çarpmaktadır. Bu ekin dışında $-r \ldots-m a z /-r . . .-m \ddot{a} z,-(l) p$ ve -kan zarf-fiilleriyle kurulan örnekler de bulunmaktadır. Diğer iki fiilimsi çeşidinde, sıfat-fiillerden -an / $\ddot{a} n$, isim-fiillerden -mek ve -maa ekleriyle kurulmuş 4 ikileme tespit edilmiştir. Bu gruptaki ikilemelerde $r . . .-m a z$ / -r....-mäz ekiyle kurulanlar hariç birinci unsur hangi fiilimsi ekini almışsa ikinci unsur da o eki almıştır.

Çekimli fiillerle kurulan ikilemelerde birinci ve ikinci unsur genellikle aynı zamanla çekime girmiştir: annat annat (GTG. 196), (KK), geziy-geziy (GD. 147), giindi kuşandı (GTTIFÇK. 217) vb. Her iki unsurun farklı bir kiple çekimlendiği iki örnek görülmüştür: gidärsän-geleceklär (GTG. 215), sayarsan-sayacaklar (GTG. 215). Yine burada aynı fiilin olumlu ve olumsuz çekiminin tekrarıyla kurulan ikilemeler dikkati çekmiştir: ağla ağlama (GÇŞA. 272), bastım-basmadım (ÇTLEK. 159), inan-inanma (GÇŞA. 272), kaldı-kalmadı (G. 36). Ayrıca birinci unsuru zarf-fiil eki alıp ikinci unsuru çekimli bir fiilden meydana gelen ikilemeler de bu başlık altında değerlendirilmiştir. Belirtilen şekildeki ikilemelerin anlama çokluk ve zıtlık katmak amacıyla kullanıldığ 1 görülmüştür: eşerdikçä eşerer (GTG. 173), gidipgelärsin (GÇŞA. 154), suuyup-terleer (SS. 64) vb.

Tespit edilen ikilemeler içerisinde ek-fiilin öğrenilen geçmiş zamanıyla çekimlenmiş sözcüklerden kurulu bir ikileme tespit edilmiştir: varmış-yokmuş (GTASGSV).

Gagauz Türkçesinde pekiştirme yoluyla kurulan ikilemeler çok kullanılır. Bu ikileme türünde diğerlerinden farklı olarak sözcük değil sözcüğün ilk hecesi belli başlı ünsüzler eklenerek ikilenir. Böylece iki ayrı sözcükten meydana gelen ikilemelerde oluğu gibi bahsedilen şekilde oluşmuş ikilemelerle de anlam pekiştirilmektedir.

Gagauz Türkçesinde ikilemeler; isim, zamir, sıfat, zarf, ünlem ve eylemlerden kurulmuştur. Zamirlerden kurulan ikilemeler, sän-bän gibi kişi zamiri, kendi-kendinä gibi dönüşlülük zamiri, te-te, onu-şunu, şu-bu, şuracıkta- buracıkta gibi işaret zamirleri, kimsin-neysin, kimä-kimä gibi soru zamirlerinden meydana gelmiştir.

Sıfatlardan meydana gelen ikilemeler aynı ya da ayrı sıfatlardan veya bir sıfatın çeşitli ünsüzlerle pekiştirilmesinden oluşmuştur. Sıfattan kurulmuş bir ikilemeden sonra gelen sözcüğün genellikle çokluk eki aldığı gözlenmiştir: ufak- tüfek işlär (KK. 56), mas-maavi göklär (SS. 5), daar daar yollar (GÇŞA. 298) vb.

Zarflardan kurulan ikilemeler de sıfatlardaki gibi aynı ya da ayrı sözcüklerden meydana gelir. Bu ikilemeler durum, zaman ve yer-yön bildiren zarflardan kuruludur. Bunun yanı sıra yansıma seslerden kurulan ikilemelerin bazıları zarf görevindedir: Harp-harp otlarmışlar. (GTG. 196). Gagauz Türkçesinde sıfatlardan ve zarflardan kurulan ikilemeler zamirlere kıyasla daha çok kullanılmaktadır.

Gagauz Türkçesinde çağırmayı, seslenmeyi, işaret etmeyi, doğa seslerini ve coşkuyu yansıtan ünlemler ikileme biçiminde kullanılmaktadır. Ünlemlerin zaman zaman üçlendiği de görülmektedir. Çalışmamızda bu şekilde bir örnek bulunmaktadır: bi-bi-bi (GRRS).

İkilemelerde aynı veya farklı kökenlerden sözcükler bir araya gelebilir. Gagauz Türkçesi ikilemelerine bu açıdan bakıldığında genellikle her iki unsurun da Türkçe kökenli sözcüklerden meydana geldiği söylenebilir. Türkçe ve yabancı sözcüklerle kurulan ikilemelerde yabancı unsurlar Arapça veya Farsça kökenli sözcüklerden oluşmaktadır Her iki unsuru yabancı isimlerden meydana gelen ikilemeler de çoğunlukla bu şekildedir. Bilindiği gibi Gagauz Türkçesi büyük ölçüde Rusçanın etkisi ve baskısı altında kalmıştır. Fakat eldeki örneklerden bu etkinin ikileme alanına yansımadığı görülmüştür. Gagauz Türkleri, Türkçe sözcükleri kullanarak oluşturdukları ikilemelerle hem anlatımlarını hem de söz varlıklarını zenginleştirmişlerdir.

Çalışmamızda Gagauz Türkçesi ikilemeleri son olarak Türkiye Türkçesinde belirlenen birtakım diziliş ilkeleri çerçevesinde değerlendirilmiştir. Bu hususla ilgili gerekli açıklamalar değerlendirme 
esnasında yapıldığından burada ayrıca detaya girilmemiştir. Ancak genel bir ifadeyle Gagauz Türkçesinde ikilemelerin Türkiye Türkçesi ikilemeleri ile benzer şekilde sıralandığı söylenebilir. Örneğin, Gagauz Türkçesi ikilemelerinde de az heceli olan sözcük çoğunlukla önce gelmiş, bunun zıddı olan ikileme örneğine daha az tesadüf edilmiştir. Bu gruptaki ikilemelerin genel olarak $1+2$ hece diziliminde olduğu tespit edilmiştir. Bundan başka eşit heceye sahip ikilemelerde ünlü ile başlayan unsurun önce gelmesi, her iki unsurun ön veya iç sesindeki ünlülerden sonra aynı ünsüzle devam etmesi, Tuna'nın tespit ettiği değişmez ünsüz sıraları gibi kuralların Gagauz Türkçesi ikilemelerinde de geçerli olduğu saptanmıştır. Değişmez ünlü sıralarından hepsine olmasa da çoğuna uyan örneklerle karşılaşılmıştır.

Gagauz Türkçesi ikilemelerinde gözlenen diğer birkaç husus şöyledir:

Osman Nedim Tuna, "Türkçede Tekrarlar" isimli çalışmasında yeşilin yeşili, hanlar hanı biçimindeki ikilemelerin "çok" anlamı verdiğini ifade etmiştir (1949: 434). Tamlama biçiminde olan bu ikilemelerin Gagauz Türkçesinde iki örneği saptanmış ve aynı fonksiyonda kullanıldığı görülmüştür: ahmakların ahmaasın (GTTIFÇK. 32), güllerin gülü (SS. 5). Söz konusu kullanımlarda aynı zamanda abartma anlamı da hissedilmektedir.

Gagauz Türkçesinde bazı ikilemeler iki şekillidir. Bir ikilemenin farklı kaynaklardan hem karpuzkaun (GÇŞA. 60) hem de kaun-karpuz (GTASGSV) şekline denk gelinmiştir. Bu durumda Gagauz Türkçesinde ikilemeyi oluşturan unsurlar bazen yer değiştirebilmektedir. Diğger örnekleri şunlardır: acı tatlı "ac1 tatlı" (GTG.197) - tatll-acı (GTG. 197), büü-küçüü (SS. 147) - küçüü-büü (GTG. 197), gecägündüz (GRRS, VUHŞŞS. 62) - gündüz-gecä (GÇŞA. 154). İmla bakımından iki ş̧ekilli olanlar ise şöyledir: çeşnä-çeşnä (GRRS) - çeşni çeşni (GHT. 138), karşı-karşıya (GRRS, GD. 173) - karşi-karşiya (MÇGRS. 231)

Sonuç itibarıyla ikilemeler, Türkçenin her döneminde ve lehçesinde olduğu gibi Gagauz Türkçesinde de yoğun olarak kullanılmakta ve çeşitlilik göstermektedir.

\section{KAYNAKÇA}

Açıkgöz, H. \& Yelten M. (2005). Kelime Grupları. İstanbul: Doğu Kütüphanesi.

Ağakay, M. A. (1954). Türkçede Kelime Koşmaları. Türk Dili Araştırmaları Yıllı̆̆ı-Belleten, C. 2, 97-104.

Aksan, D. (2006). Anadilimizin Söz Denizinde. Ankara: Bilgi Yayınevi.

Aksan, D. (2016). AnlamBilim. Ankara: Bilgi Yayınevi.

Argunşah, M. \& Argunşah H. (2007). Gagauz Yazıları. Kayseri: Türk Ocakları Kayseri Şubesi. (GY)

Arnaut, T. (2009). Gagauz Türkülerinde Așk ve Ölüm Motifleri. Hacettepe Üniversitesi Türkiyat Araşttrmaları Dergisi, C. 11, S. 11, 5-20. (GTAÖM)

Atmaca, E. ve Kral, F. (2015). Kazak Türkçesindeki İkilemelerin Sınıflandırılması. Uluslararası Türkçe Edebiyat Kültür Ĕ̈itim Dergisi, S. 4/1, 194-213.

Aydın, E. (1997). Orhon Yazıtlarında Hendiadyoinler. Türk Dili Dergisi, 544, 417-421.

Banguoğlu, T. (2015). Türkçenin Grameri. Ankara: Türk Dil Kurumu Yayınları.

Baymak, O. (2000). Gagauz Çağdaş Şiiri Antolojisi. Ankara: Bilig Yayınları. (GÇŞA)

Can, M. (2010). Eski Uygur Türkçesinde İkilemeler. Yüksek Lisans Tezi, Uludağ Üniversitesi, Bursa.

Chırlı, N. (2005). Gagavuz Türkçesinde Yeterlik Yapıları Üzerine. Türk Dünyası Dil ve Edebiyat Dergisi, S. 19, 5561. $($ GTYYÜ)

Çağatay, S. (1978). Uygurcada Hendiadyoinlar. Dil ve Tarih Coğrafya Fakültesi Ylllık Çalışmalar Dergisi, S.1, 97144.

Çağdaş Türk Lehçeleri El Kitabı (2007). (Ed. Levent Doğan). İstanbul: Paradigma Yayınları. (ÇTLEK)

Çebotar, P. \& Dron, I. (2002). Gagauzça-Rusça-Romınca Sözlük. Chişinau: Pontos. (GRRS)

Çelik, M. \& Yılmaz, M. (2020). Türkiye'de Yayımlanan Çalışmalar Işı̆̆ında Kaşkay Türkçesinde İkilemeler. Türk Dünyası Dil ve Edebiyat Dergisi, S. 50, 47-76.

Dilek, F. G. (2004). Altay Türkçesinde İkilemeler. Bilig, S. 28, 83-100.

Doğan, L. (2012). Türkmen Türkçesinde İkilemeler. ODÜ Sosyal Bilimler Enstitüsü Sosyal Bilimler Araştırmaları Dergisi, C. 3 S. 6, 90-103. 
Doğan L. \& Erdin C. (2019). Gagauz Atasözlerinin Sentaksı Üzerine Bir Değerlendirme. Turkish Studies- Language and Literature, Volume 14, Issue 3, 1159-1187. (GASÜBD)

Erdin, C. \& Doğan, L. (2020). Kadem Kaynaa Romanının Söz Varlığı Üzerine Bir Değerlendirme. RumeliDE Dil ve Edebiyat Araştırmaları Dergisi, (Ö7), 15-38. (KKRSVÜBम்)

Eren, H. (1949). İkiz Kelimelerin Tarihi Hakkında. DTCF Dergisi., C. 7, S. 2, 283-286.

Ergin, M. (2013). Türk Dil Bilgisi. İstanbul: Bayrak Yayınları.

Gencan, T. N. (1979). Dilbilgisi (4. Baskl). Ankara: Türk Dil Kurumu Yayınları.

Güngör H. \& Argunşah, M. (1998). Gagauzlar (Gagauz Türklerinin etnik yapısı, nüfusu, dili, dini, folkloru hakkında bir araştırma). İstanbul: Ötüken Neşriyat. $(G)$

Hatiboğlu, V. (1981). Türk Dilinde Íkileme. Ankara: Türk Dil Kurumu Yayınları.

Hünerli, B. (2013). Gagavuz Türkçesindeki Çok Anlamlı “Uur (Uğur)” Sözcüğü Üzerine. TÜRÜK Uluslararası Dil ve Edebiyat Dergisi, C.1, S. 2, 351-358. (GTÇAUSÜ)

Hünerli, B. (2019). Mihail Çakir’in Gagauzca (Türkçe)-Rumence Sözlüğ̈̈ (İnceleme- Metin). Çanakkale: Paradigma Akademi. (MÇGRS)

Hünerli, B. (2019). Soluyan Sözler. Çanakkale: Paradigma Akademi. (SS)

Hünerli, B. (2019). Gagauz Atasözlerinde “At”. TÜRÜK Uluslararası Dil, Edebiyat ve Halkbilimi Araştırmaları Dergisi. Y. 7, S. 16, 108-116. (GAA)

Hünerli, B. (2019). Ukrayna Gagauzlarından Şair Vasiliy Uzunov’un Hayatı, Şiirleri ve Şiirlerindeki Söz Varlığı. Karadeniz Araştırmaları, XVI/61, 56-65. (VUHŞŞS)

Kara, M. (2009). Hakas Türkçesinde İkilemeler. Gazi Türkiyat Türkoloji Araştırmaları Dergisi, C.1, S. 4, $35-62$.

Karahan, L. (2013). Türkçede Söz Dizimi. Ankara: Akçay Yayınları.

Kaya, M. M. (2018). Gagauz Türkçesinin “Ana Sözü” Gazetesindeki Söz Varlı̆̆l (2012-2016). Yüksek Lisans Tezi, Kocaeli Üniversitesi Sosyal Bilimler Enstitüsü, Kocaeli. (GTASGSV)

Kardeş, R. (2015). Yakut (Saha) Türkçesinde İkilemeler. Siberian Studies (SAD), 3 (8), 35-60.

Korkmaz, Z. (2010). Gramer Terimleri Sözlüğü. Ankara: Türk Dil Kurumu Yayınları.

Kösä, M. (1996). Gülümsemää Diyl Günaa. (GDG)

Manov, A. (2001). Gagauzlar (Hıristiyan Türkler (Bulgarcadan çev. M. Türker Acaroğlu). Anakara: Türk Tarih Kurumu Basimevi. (GHT)

Nedeva, A. (2008). Gagavuzca ve Türkiye Türkçesinde Ísim ve Fiil Çekimi Karşılaştırması. Yüksek Lisans Tezi, İstanbul Üniversitesi, İstanbul. (GTTİFÇK)

Ölmez, M. (2017). Eski Uygurca İkilemeler Üzerine. Türk Dili Araştırmaları Yıllı̆̆ı-Belleten, C. 65, S. 2, $243-311$.

Öz, A. (1997). Özbek Türkçesinde İkilemeler. Türkoloji Dergisi, 12(1), 287-311.

Özkan, N. (1996). Gagavuz Türkçesi Grameri. Ankara: Türk Dil Kurumu Yayınları. (GTG)

Özkan, N. (2007). Gagavuz Destanlarl. Ankara: Türk Dil Kurumu Yayınları. (GD)

Özşahin, M. (2017). Tatar ve Başkurt Yazı Dillerinde İkilemeler. İstanbul: Kesit Yayınları.

Öztürk, S. (2008). Yeni Uygur Türkçesinde İkilemeler. Turkish Studies International Periodical For the Languages, Literature and History of Turkish or Turkic, 3(4), 1036-1048.

Savran, A. F. (2019). Gagavuz Türkçesinde Slfatlar. Yüksek Lisans Tezi, Afyon Kocatepe Üniversitesi Sosyal Bilimler Enstitüsü, Afyonkarahisar. (GTS)

Şen, S. (2002). Eski Uygur Türkçesinde İkilemeler. Yüksek Lisans Tezi, On Dokuz Mayıs Üniversitesi, Samsun.

Tuna, O. N. (1983). Türkçenin Sayıca Eş Heceli İkilemelerinde Sıralama Kuralları ve Tabiî Bir Ünsüz Dizisi. Türk Dili Araştırmaları Yıllı̆̆g-Belleten, C. 30-31, S. 1982-1983, 163-228.

Tuna, O. N. (1949). Türkçede Tekrarlar. İstanbul Üniversitesi Edebiyat Fakültesi Türk Dili ve Edebiyatı Dergisi, C. 3, S. 2-3, 429-447.

Ulutaş, İ. (2007). Kırgız Türkçesinde İkilemeler. Akademik Bakış, S. 13, 1-15.

Ulutaş, İ. (2012). Gagauz Türkçesi Söz Diziminde Yabancı Dillerden Etkilenmeler Üzerine Bir Değerlendirme. Türk Dünyası Araştırmaları, S. 197, 227-239. (GTSYDEÜBD) 
Vardar, B. (2002). Açıklamalı Dilbilim Terimleri Sözlüğü. İstanbul: Multılıngual.

Yalçın, S. K. \& Çeçen, E. (2020). Azerbaycan Türkçesi Sözlüğündeki İkilemeler Üzerine Bir Değerlendirme. Túrkologıa, № 6 (104), 32-44.

Yücel, E. (2016). Karşılaşırımalı Bir Bakış Açısıyla Türkçe ve Almanca İkilemeler. Selçuk Üniversitesi Edebiyat Fakültesi Dergisi, S. 36, 79-96.

\section{Dil Kisaltmaları}

Ar.: Arapça

Fa.: Farsça

Fr.: Fransizca

Rus.: Rusça

Rumn.: Rumence

Rum.: Rumca 